\title{
ASSESSING MACRO-NUTRIENT REMOVAL POTENTIAL OF NINE NATIVE PLANT SPECIES GROWN AT A SEWAGE SLUDGE DUMP SITE
}

\author{
AbDallah, S. M. ${ }^{1,2,3}$ - FARAhat, E. A. ${ }^{4}$ - Shaltout, K. H. ${ }^{5}$ - EID, E. M. ${ }^{1,6^{*}}$ \\ ${ }^{1}$ Biology Department, College of Science, King Khalid University, Abha 61321, P.O. Box 9004, \\ Saudi Arabia \\ ${ }^{2}$ Prince Sultan Bin Abdul-Aziz Center for Environment and Tourism Research and Studies, King \\ Khalid University, Abha 61421, P.O. Box 960, Saudi Arabia \\ ${ }^{3}$ Department of Soils and Water, Faculty of Agriculture, Ain Shams University, P.O. Box 68, \\ Hadayek Shoubra, 11241 Cairo, Egypt \\ ${ }^{4}$ Botany and Microbiology Department, Faculty of Science, Helwan University, Cairo, Egypt \\ ${ }^{5}$ Botany Department, Faculty of Science, Tanta University, 31527 Tanta, Egypt \\ ${ }^{6}$ Botany Department, Faculty of Science, Kafr El-Sheikh University, 33516 Kafr El-Sheikh, \\ Egypt \\ *Corresponding author \\ e-mail:ebrahem.eid@sci.kfs.edu.eg,eeid@kku.edu.sa,ebrahem.eid@gmail.com; phone:+966- \\ 55-271-7026; fax: +966-17-241-8205
}

(Received $19^{\text {th }}$ Oct 2019; accepted $8^{\text {th }}$ Jan 2020)

\begin{abstract}
Searching for new plants that could phytoextract soil macro-nutrients is one of the main research interests nowadays. In the present study, nine native plant species were collected to determine their potential to uptake six macro-nutrients from the soil of a sewage sludge dump site (SS) in comparison with a reference site (RS). The results showed that the studied native plants can accumulate the macro-nutrients in their tissues regardless of their size or vegetative stages. The concentrations of all macro-nutrients (except K) in the tissues of the most studied plant species were positively correlated with those in the soil. The stoichiometric ratios vary among species and depend on many limiting factors. The values of bioaccumulation and translocation factors were $>1.0$, indicating the high tendency of the plants to accumulate the macro-nutrients. Portulaca oleracea growing in the SS accumulated larger quantities of macro-nutrients compared to two perennials growing at the same place. Phragmites australis, Rumex dentatus, Portulaca oleracea, Bassia indica, Amaranthus viridis and Pluchea dioscoridis from the SS; and Portulaca oleracea, Rumex dentatus, Pluchea dioscoridis and Solanum nigrum from the control site showed the highest element accumulation indices, which could be recommended for the phytoextraction of macro-nutrients. We recommend using the studied species in mitigation of the eutrophic status of agricultural soil amended with sewage sludge.
\end{abstract}

Keywords: bioindicator, biosolids, Nile delta, nutrient elements, phytoextraction, wastewater treatment plants, wild plants

\section{Introduction}

Sewage sludge is defined as an organic byproduct of the treatment of municipal and/or industrial wastewater. It contains high amounts of macro-nutrients and heavy metals (Eid and Shaltout, 2016). It is used as fertilizers in many agricultural lands and it has significant positive influences on soil fertility and plant macro-nutrients (Aráujo et al., 2007). On the other hand, the presence of toxic levels of heavy metals in the sludge 
due to the contribution of industrial effluents may have adverse effects on agriculture and food chain (Singh and Agrawal, 2007; Eid et al., 2018a). Moreover, availability of nitrogen and phosphorus from sludge-amended soils and their transfer in runoff may lead to eutrophication of soil and downstream surface water (Quilbé et al., 2005). The worldwide production of sewage sludge is increasing with the populations, as well as their use as soil amendments on agricultural lands (Moreno-Caselles et al., 1997; Eid et al., 2018a). Numerous studies on the use of sewage sludge as soil amendments have been conducted on agricultural crops, wood- and wetlands (e.g., Fuentes et al., 2007; Yu et al., 2014; Eid et al., 2017a, b, 2018b, 2019, 2020a, b, c). Few studies were conducted on wild native plants (e.g., Ho and Wong, 1994; Korboulewskya et al., 2002; Farahat and Linderholm, 2013; Eid and Shaltout, 2016).

Native plants are key species in the ecosystems and play important roles in degrading and removing macro-nutrients, heavy metals, and other pollutants from the environment (Eid and Shaltout, 2016). This green technology is called "Phytoremediation" (Peng et al., 2008). It includes many methods, one of them is phytostabilization, where plants are used to immobilize metals and store them in their below-ground tissues and/or soil. In addition, plants may play an important role in element removal (phytoextraction) through many ways, such as absorption and cation exchange (Chandra et al., 2017).

Many studies were conducted to investigate the influences of sewage sludge on the growth, yield and solute contents in crops and forest trees (e.g. Henry et al., 1994; Antolín et al., 2010; Singh and Agrawal, 2010). Some other studies tried to identify the health risks that could be associated with using sewage sludge and/or sewage wastewater in agriculture (e.g., Singh and Agrawal, 2007; Galal, 2016; Farahat et al., 2017; Eid et al., 2018a). Most of these studies were interested in evaluating the role of plants in phytoremediation of heavy metals, but not macro-nutrients. The soil pollution by macro-nutrients is unusual, but especially problematic when involves eutrophication. These levels of high concentrations of macro-nutrients in the soil will adversely affect the biodiversity of native species and it may introduce only the species that grow well on eutrophic soil (El-Sheikh et al., 2012; Shaltout et al., 2019). In addition, over-use of sewage sludge in agricultural practices may lead to over concentrations of macronutrients that lead to eutrophication of soil and downstream surface water (Quilbé et al., 2005). The application of sewage sludge in high quantities to the agricultural lands without prior knowledge to its chemical structure may lead to presence of high nondesirable concentrations of macro-nutrients (Quilbé et al., 2005). Presence of native species that able to uptake extra concentrations of macro-nutrients and reduce the macro-nutrient loads in soil will represent a good service to the ecosystem.

Wild plants play an important role in macro-nutrient cycling through uptake, sequestering and release of macro-nutrient elements (Eid et al., 2012a). Utilization of these wild plants as phytoremediators in eutrophic habitats requires emphasis on the effect of macro-nutrient loadings on these plants, but this effect has received little attention and is still not well understood (Eid et al., 2010; Zhao et al., 2013). According to the authors' knowledge, so far no studies have been carried out in Egypt on the grown plant of native species at a sewage sludge dump site in comparison with the reference site in the context of their usefulness for macro-nutrients phytoremediation. Therefore, the wider objective of this study was to assess the removal efficiency of macro-nutrients by nine native plant species grown at a sewage sludge dump site (SS) in Egypt. The specific objectives of the present study were to: (1) to assess the ability of nine Tropical and Mediterranean native plant species grown on SS to accumulate 
macro-nutrients in their tissues compared to a reference site (RS); and (2) to examine the roles of these nine species as potential bioindicators of macro-nutrients. The results of the present study could be useful when designing a phytoremediation system.

\section{Materials and methods}

\section{Study area}

The study area is the dump site of Kafr El-Sheikh Wastewater Treatment Plant in the northern Nile Delta, Egypt (Lat. $31^{\circ} 05^{\prime} 05.42^{\prime \prime} \mathrm{N}$, Long. 30 $0^{\circ} 57^{\prime} 43.24^{\prime \prime} \mathrm{E}$ ), and the adjacent agricultural farms are the reference site (RS) (Lat. 31 $04^{\prime} 53.46^{\prime \prime} \mathrm{N}$, Long. $30^{\circ}$ $\left.57^{\prime} 31.60^{\prime \prime} \mathrm{E}\right)$. The RS is located about $1 \mathrm{~km}$ away from the dump site and its soil type is clay. The climatic conditions are warm summers $\left(20\right.$ to $\left.30^{\circ} \mathrm{C}\right)$ and mild winters $\left(\geq 10^{\circ} \mathrm{C}\right)$ (EMA, 1980).

\section{Field sampling process}

The sampling process was carried out at six locations, three of which represent each of the SS and RS (Fig. 1). Nine native plant species dominating the study area were chosen at each site (Amaranthus viridis L.: Amaranthaceae, slender amaranth, annual herb, often 60-80 cm tall; Bassia indica (Wight) A. J. Scott: Amaranthaceae, kochia, annual richly branched herb, often $2 \mathrm{~m}$ tall; Conyza bonariensis (L.) Cronquist: Asteraceae, flax-leaf fleabane, annual herb, often $75 \mathrm{~cm}$ tall; Portulaca oleracea L.: Portulacaceae, common purslane, glabrous fleshy herb, may reach $40 \mathrm{~cm}$ in height; Rumex dentatus L.: Polygonaceae, toothed dock, annual or biennial herb, erect stem up to $70-80 \mathrm{~cm}$ in height; Solanum nigrum L.: Solanaceae, black nightshade, herb or shortlived perennial shrub, often 30-120 cm tall; Lycopersicon esculentum Mill.: Solanaceae, tomato, perennial in native habitat, but cultivated as annual, grows up to 1-3 $\mathrm{m}$ in height. Phragmites australis (Cav.) Trin. ex Steud.: Poaceae, common reed, perennial robust reed, erect stem up to $5 \mathrm{~m}$ in height; and Pluchea dioscoridis (L.) DC.: Asteraceae, camphorweeds, richly branched hairy shrub, often 2-3 m high). For each plant species, three mature and healthy replicates were collected from each sampling location during May 2014. Plants were identified following Boulos (1999, 2002, 2005). In the laboratory, samples were carefully washed with tap water over a $4 \mathrm{~mm}$ mesh sieve to minimize material loss, separated into leaves, stems and roots, oven dried at $85^{\circ} \mathrm{C}$ to a constant weight, and then ground using a metal-free plastic mill. Roots were collected by excavated carefully around the root system of each plant. At each sampling location, a composite soil sample was collected as a profile from three holes, each about $20 \mathrm{~cm}$ deep. The soil samples were air dried and passed through a $2 \mathrm{~mm}$ sieve to separate gravel and debris.

\section{Chemical analysis}

Soil samples were analyzed for organic matter $(\mathrm{OM})$ content using loss-on-ignition method at $550{ }^{\circ} \mathrm{C}$ for $2 \mathrm{~h}$ (Wilke, 2005). Soil-water extracts at 1:5 were prepared for the determination of $\mathrm{pH}$ and electric conductivity (EC). Macro-nutrients (except $\mathrm{N}$ ) in soil and plant samples were extracted from 0.5 to $1 \mathrm{~g}$ using a mixed-acid digestion method. $\mathrm{EC}$ and $\mathrm{pH}$ were measured using conductivity and $\mathrm{pH}$ meters, respectively. Calcium, $\mathrm{Mg}, \mathrm{Na}$ and $\mathrm{K}$ were determined by atomic absorption, while total $\mathrm{P}$ was determined by spectrophotometer using the ammonium-molybdate method. Total $\mathrm{N}$ was determined in 
plant and soil samples using a CHN Elemental Analyzer (Yanako CHN Corder MT-5, Japan). All these procedures are outlined in Allen (1989) and APHA (1998).

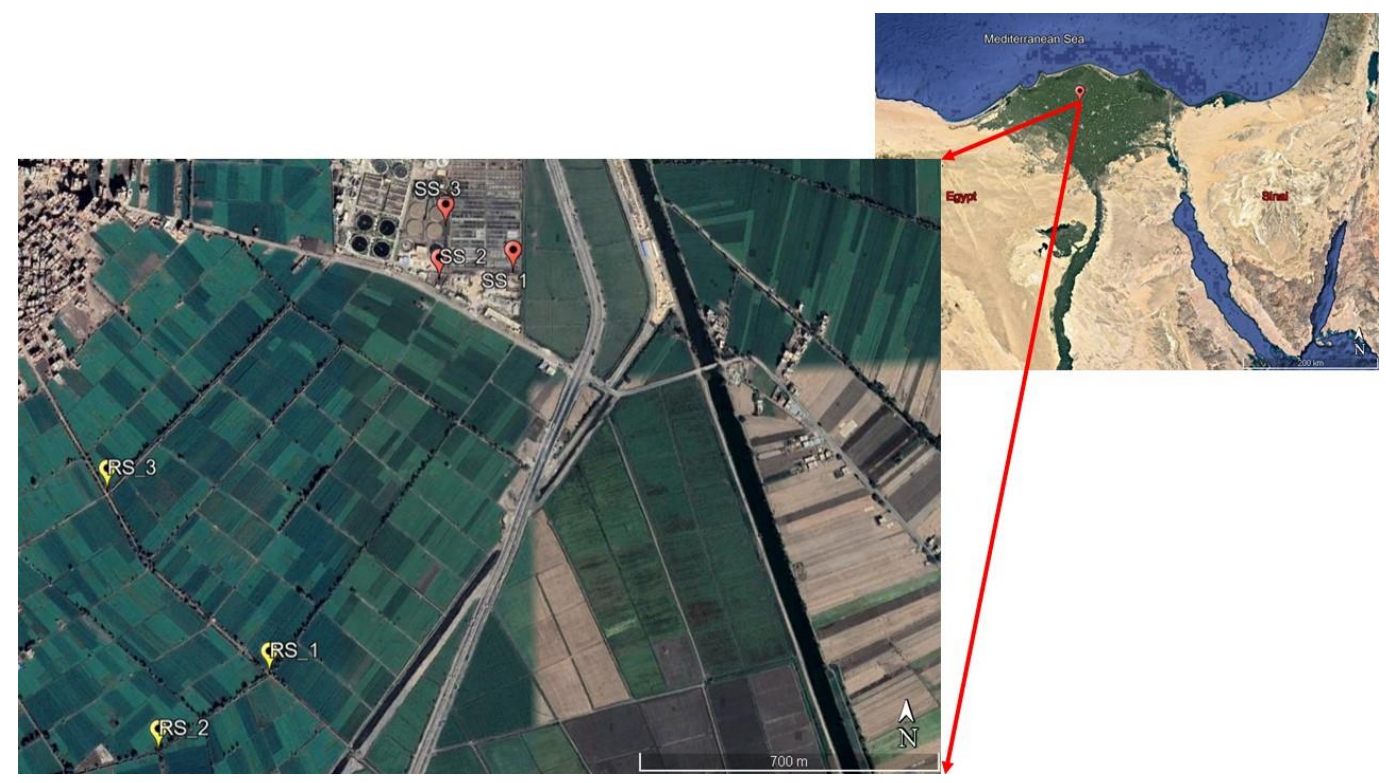

Figure 1. Location map of study area showing the sampling sites. SS: sewage sludge dump site, RS: reference site

\section{Calculations}

The bioaccumulation factor $(\mathrm{BF})$ was calculated to determine the efficiency of the plant for accumulating a macro-nutrient from the soil (Xiao et al., 2011):

$$
B F=\frac{\text { Concentration of a macronutrient in belowground tissues }(\mathrm{mg} / \mathrm{kg})}{\text { Concentration of the same macronutrient in soil at the same site }(\mathrm{mg} / \mathrm{kg})}
$$

The translocation factor (TF) was calculated to depict the ability of plants to translocate a macro-nutrient from below- to above-ground tissues (Gupta et al., 2008):

$$
T F=\frac{\text { Concentration of a macronutrient in aboveground tissues (mg/kg) }}{\text { Concentration of a macronutrient in belowground tissues (mg/kg) }}
$$

The element accumulation index (EAI) was used to assess the overall performance of macro-nutrient accumulation in plants (Liu et al., 2007):

$$
E A I=(1 / N) \sum_{j=1}^{N} I j ; I j=\frac{x}{\delta x}
$$

where $N$ is the total number of the analyzed macro-nutrients and $I_{j}$ is the sub-index for a macro-nutrient $j$, obtained by dividing the mean concentration of a macro-nutrient $(x)$ by its standard deviation $(\delta x)$.

\section{Statistical analysis}

Before performing an analysis of variance (ANOVA), the data were tested for their normality of distribution (Shapiro-Wilk's W test) and homogeneity of variance (Levene's 
test), and when necessary, the data were log-transformed. Macro-nutrients data for nine plant species were subjected to a three-way ANOVA (the assumptions have been met) to identify the interactions in the independent variables (species, tissues, and sites). The significance of variation in the relative concentrations of the different macro-nutrients (considering whole plant), one species at a time at the two different sites (SS/RS) was assessed using a paired $t$-test, while one-way ANOVA was used to analyze the variation among species within the same site. The significant differences between means, among the nine plant species were identified using the Tukey HSD test at $P<0.05$. The significance of variation in soil quality parameters between the SS and RS was assessed using a paired $t$-test. EAI data for nine plant species were subjected to a two-way analysis of variance (ANOVA-2) to test the differences between species and sites. Correlations between the concentrations of macro-nutrients in plant tissues and soil samples (the SS and RS) were evaluated using the Pearson's $r$ coefficient. Statistical analyses were carried out using Statistica 7.1 (Statsoft, 2007). Stochiometric ratios were calculated for some of the analyzed macro-nutrients. To identify statistically significant differences in the stochiometric ratios among different sites, the paired $t$-test was performed.

\section{Results}

The soil of the SS was rich in OM, N, P, Ca and it was also slightly acidic, while EC, $\mathrm{Mg}, \mathrm{Na}$ and $\mathrm{K}$ concentrations of the RS were significantly higher than those of the SS (Table 1). Macro-nutrient concentrations in the soil of the SS had the following sequence: $\mathrm{Ca}>\mathrm{N}>\mathrm{Mg}>\mathrm{Na}>\mathrm{K}>\mathrm{P}$; while in soil of the RS the sequence was: $\mathrm{Ca}>\mathrm{Na}>\mathrm{Mg}>\mathrm{K}>\mathrm{N}>\mathrm{P}$.

Table 1. Mean \pm standard error $(n=3)$ of soil physico-chemical characteristics for sewage sludge dump site and reference site, where the present study was carried out

\begin{tabular}{c|c|c|c|c}
\hline Characteristics & Sewage sludge dump site & Reference site & $\boldsymbol{t}$-value & $\boldsymbol{p}$ \\
\hline $\mathrm{EC}\left(\mathrm{mS} \mathrm{cm}^{-1}\right)$ & $0.04 \pm 0.01$ & $3.46 \pm 0.08$ & 38.9 & 0.001 \\
$\mathrm{pH}$ & $6.40 \pm 0.08$ & $7.76 \pm 0.03$ & 14.8 & 0.000 \\
$\mathrm{OM}(\%)$ & $51.50 \pm 0.23$ & $6.74 \pm 0.07$ & 148.6 & 0.000 \\
$\mathrm{~N}\left(\mathrm{mg} \mathrm{g}^{-1}\right)$ & $30.27 \pm 0.52$ & $2.00 \pm 0.23$ & 37.9 & 0.001 \\
$\mathrm{P}\left(\mathrm{mg} \mathrm{g}^{-1}\right)$ & $2.36 \pm 0.09$ & $0.89 \pm 0.02$ & 14.9 & 0.000 \\
$\mathrm{Ca}\left(\mathrm{mg} \mathrm{g}^{-1}\right)$ & $53.36 \pm 0.57$ & $40.90 \pm 1.39$ & 10.1 & 0.000 \\
$\mathrm{Mg}\left(\mathrm{mg} \mathrm{g}^{-1}\right)$ & $6.34 \pm 0.18$ & $8.29 \pm 0.29$ & 6.3 & 0.000 \\
$\mathrm{Na}\left(\mathrm{mg} \mathrm{g}^{-1}\right)$ & $6.22 \pm 0.26$ & $8.50 \pm 0.20$ & 15.5 & 0.000 \\
$\mathrm{~K}\left(\mathrm{mg} \mathrm{g}^{-1}\right)$ & $4.69 \pm 0.07$ & $6.03 \pm 0.13$ & 14.7 & 0.000 \\
\hline
\end{tabular}

t-values represent the paired t-test, EC: electric conductivity, OM: organic matter content

Regarding the studied plant species, concentrations of N, P and Na were significantly affected by site; those of $\mathrm{N}, \mathrm{Ca}, \mathrm{Mg}$ and $\mathrm{Na}$ were significantly affected by plant species, while those of $\mathrm{N}, \mathrm{Ca}, \mathrm{Mg}$ and $\mathrm{K}$ were significantly affected by plant tissue (Table 2). $\mathrm{N}$, $\mathrm{P}$ and $\mathrm{K}$ concentrations were significantly higher in the plant species of the $\mathrm{SS}$ as compared to the RS (Table 3; Appendix 1). In addition, concentrations of $\mathrm{N}, \mathrm{P}, \mathrm{Ca}, \mathrm{Mg}$ and $\mathrm{Na}$ were higher in the leaf; but $\mathrm{K}$ was higher in the stem. The highest $\mathrm{N}, \mathrm{P}$ and $\mathrm{K}$ concentrations (48.2, 3.2 and $80.2 \mathrm{mg} \mathrm{g}^{-1}$, respectively) was observed in P. oleracea 
grown at the SS, while the lowest (17.7, 0.3 and $17.7 \mathrm{mg} \mathrm{g}^{-1}$, respectively) was observed in $P$. dioscoridis, A. viridis, $C$. bonariensis and $P$. australis grown at the RS (Table 3). The highest $\mathrm{Ca}$ and $\mathrm{Mg}$ concentrations (45.1 and $15.2 \mathrm{mg} \mathrm{g}^{-1}$ ) were observed in L. esculentum and P. oleracea has grown at the RS, while the lowest ( 8.9 and $1.4 \mathrm{mg} \mathrm{g}^{-1}$ ) were observed in $P$. australis has grown at the same site. The highest $\mathrm{Na}$ concentration $\left(53.0 \mathrm{mg} \mathrm{g}^{-1}\right)$ was recorded in $B$. indica has grown at the SS, while the lowest $\left(2.8 \mathrm{mg} \mathrm{g}^{-1}\right)$ was detected in $S$. nigrum has grown at the RS.

Table 2. Results of three-way ANOVA (F-values) of macro-nutrients concentrations of nine native plant species in north Nile Delta, Egypt

\begin{tabular}{c|c|c|c|c|c|c|c}
\hline \multirow{2}{*}{ Effect } & \multirow{2}{*}{$\boldsymbol{d} f$} & \multicolumn{7}{c}{ Dependent variables } \\
\cline { 3 - 8 } & & $\mathbf{N}$ & $\mathbf{P}$ & $\mathbf{C a}$ & $\mathbf{M g}$ & $\mathbf{N a}$ & $\mathbf{K}$ \\
\hline Site & 1 & $55.4^{* *}$ & $9.2^{*}$ & $0.1^{\mathrm{ns}}$ & $2.1^{\mathrm{ns}}$ & $9.3^{*}$ & $1.3^{\mathrm{ns}}$ \\
Species & 8 & $4.4^{*}$ & $0.7^{\mathrm{ns}}$ & $6.4^{* *}$ & $5.5^{* *}$ & $4.8^{* *}$ & $2.2^{\mathrm{ns}}$ \\
Tissue & 3 & $63.1^{* * *}$ & $4.5^{\mathrm{ns}}$ & $16.7^{* *}$ & $8.2^{* *}$ & $2.6^{\mathrm{ns}}$ & $4.8^{*}$ \\
Site $\times$ Species & 8 & $1.3^{\mathrm{ns}}$ & $2.7^{*}$ & $4.3^{* *}$ & $4.7^{* *}$ & $1.9^{\mathrm{ns}}$ & $4.3^{* *}$ \\
Site $\times$ Tissue & 3 & $0.8^{\mathrm{ns}}$ & $0.6^{\mathrm{ns}}$ & $0.2^{\mathrm{ns}}$ & $1.2^{\mathrm{ns}}$ & $1.2^{\mathrm{ns}}$ & $2.6^{\mathrm{ns}}$ \\
Species $\times$ Tissue & 16 & $2.0^{\mathrm{ns}}$ & $1.1^{\mathrm{ns}}$ & $1.9^{\mathrm{ns}}$ & $10.2^{* * *}$ & $4.9^{* *}$ & $4.4^{* *}$ \\
Site $\times$ Species $\times$ Tissue & 16 & $36.5^{* * *}$ & $20.9^{* * *}$ & $22.7^{* * *}$ & $16.3^{* * *}$ & $53.9^{* * *}$ & $18.9^{* * *}$ \\
\hline
\end{tabular}

Site: Sewage sludge dump site/Reference site, Species: nine native plant species, Tissue: fruit/leaf/stem/root. *: $\mathrm{p}<0.05$, **: $\mathrm{p}<0.01$, ***: $\mathrm{p}<0.001$, ns: not significant (i.e., $\mathrm{p}>0.05$ ), df: degree of freedom

All the investigated species were characterized by a bioaccumulation factor (BF) $>1.0$ for some macro-nutrients (Fig. 2). A. viridus showed the higher BF value for $\mathrm{K}$ (14.4), P. oleracea showed higher BF values for $\mathrm{N}$ (1.3), $\mathrm{P}$ (1.6) and $\mathrm{Mg}$ (1.5), $R$. dentatus showed the higher $\mathrm{BF}$ value for $\mathrm{Na}$ (3.3). At the RS, B. indica showed the higher $\mathrm{BF}$ value for $\mathrm{Na}(2.8)$, P. oleracea showed higher $\mathrm{BF}$ values for $\mathrm{N}$ (12.3) and $\mathrm{Mg}$ (0.9), L. esculentum showed higher $\mathrm{BF}$ values for $\mathrm{P}(3.6)$ and $\mathrm{Ca}(1.1)$, and $P$. dioscoridis showed the higher BF value for $\mathrm{K}$ (6.9).

In the present study, the translocation factor (TF) varied among the studied sites, plant species and among the macro-nutrients (Fig. 3). Regarding the SS, A. viridus had the highest $\mathrm{TF}$ for $\mathrm{Mg}$ (3.8), B. indica for $\mathrm{Na}$ (5.2), P. oleracea for K (1.6), S. nigrum for N (2.2), L. esculentum for $\mathrm{P}$ (2.0) and P. dioscoridis for $\mathrm{Ca}$ (2.3). At the RS, B. indica had the highest TF for $\mathrm{P}$ (98.0), C. bonariensis for $\mathrm{Mg}$ (3.12), P. oleracea for $\mathrm{Ca}$ (1.9) and $\mathrm{Na}$ (3.4), and $R$. dentatus for $\mathrm{N}$ (4.1) and $\mathrm{K}$ (2.0).

Element accumulation index (EAI) were significantly higher in all plant species at the SS as compared to the RS (except $C$. bonariensis and P. dioscoridis; Fig. 4). The species with the highest EAI at the SS were $P$. oleracea (41.6), followed by $P$. australis (30.6), $R$. dentatus (27.7), P. dioscoridis (27.4), A. viridis (26.9) and B. indica (26.7). In contrast, $C$. bonariensis showed the lowest EAI value (19.2). In addition, $P$. oleracea (31.0), followed by $P$. dioscoridis (29.5), $R$. dentatus (24.7) and $S$. nigrum (24.5) that had the highest EAI in the RS, while $P$. australis (16.3) had the lowest. Positive linear correlations were detected between $\mathrm{N}, \mathrm{P}, \mathrm{Ca}, \mathrm{Mg}$ and $\mathrm{Na}$ concentrations in all tissues of $A$. viridus and the soil of both sites (Appendix 2); N, P, Ca and Na for B. indica; N and $\mathrm{P}$ for $C$. bonariensis; $\mathrm{N}, \mathrm{P}, \mathrm{Ca}$ and $\mathrm{Na}$ for P. oleracea; Ca for R. dentatus; N, P, Mg and $\mathrm{Na}$ for S. nigrum; N and $\mathrm{Na}$ for L. esculentum; N, P, Ca and $\mathrm{Na}$ for P. australis; $\mathrm{N}$ for $P$. dioscoridis. 
Table 3. Mean macro-nutrients concentrations \pm standard errors in nine native plant species that grown at sewage sludge dump site (SS) and reference site $(R S)$ in north Nile Delta,

Egypt. (Detailed values for each tissue are present in Appendix 1)

\begin{tabular}{|c|c|c|c|c|c|c|c|}
\hline \multirow{2}{*}{ Species } & \multirow{2}{*}{ ite } & \multicolumn{6}{|c|}{ Macro-nutrient $\left(\mathrm{mg} \mathrm{g}^{-1}\right)$} \\
\hline & & $\mathbf{N}$ & $\mathbf{P}$ & $\mathbf{C a}$ & Mg & $\mathbf{N a}$ & $\mathbf{K}$ \\
\hline \multirow{3}{*}{ A. viridis } & & $9 \pm$ & $2.0 \pm$ & $\mathrm{Ob}$ & & & $65.6 \pm$ \\
\hline & $\mathrm{RS}$ & $23.7 \pm 4.8 \mathrm{a}$ & $0.3 \pm 0.1 \mathrm{ab}$ & $29.0 \pm 1.9 \mathrm{bc}$ & $11.5 \pm 1.5 \mathrm{c}$ & $7.0 \pm 0.4 \mathrm{a}$ & $49.9 \pm 5.7 b$ \\
\hline & alue & $22.2 * * *$ & $29.8 * * *$ & $9.3 * * *$ & 10.3* & $7.4 * * *$ & $4.3 * *$ \\
\hline \multirow{3}{*}{ B. indica } & $\mathrm{C}$ & $3.4 \pm 4.4 \mathrm{ab}$ & $2.8 \pm 0.1 \mathrm{~cd}$ & $16.9 \pm 1.5 \mathrm{a}$ & $4.2 \pm 0.6 \mathrm{ab}$ & $37.5 \pm 7.3 d$ & $44.3 \pm 3.5 \mathrm{a}$ \\
\hline & $\mathrm{RS}$ & $25.5 \pm 3.7 \mathrm{a}$ & $0.7 \pm 0.2 \mathrm{abc}$ & $11.0 \pm 0.8 \mathrm{a}$ & $3.2 \pm 0.2 \mathrm{ab}$ & $53.0 \pm 7.3 \mathrm{c}$ & $46.5 \pm 2.2 b$ \\
\hline & ue & $9.1 *$ & $16.3 * * *$ & $5.7 * * *$ & $2.4 *$ & 6.6 & $0.6^{\mathrm{ns}}$ \\
\hline \multirow{3}{*}{$\begin{array}{c}C . \\
\text { bonariensis }\end{array}$} & SS & & & & & & $39.0 \pm 2.3 \mathrm{a}$ \\
\hline & RS & $22.7 \pm 3.9 \mathrm{a}$ & $0.3 \pm 0.1 \mathrm{a}$ & $17.6 \pm 1.2 \mathrm{ab}$ & $3.2 \pm 0.6 \mathrm{ab}$ & $14.6 \pm 2.9 \mathrm{ab}$ & $38.0 \pm 2.5 b$ \\
\hline & $t$-value & $3.4 * *$ & $5.2 * *$ & $2.2^{\mathrm{ns}}$ & $0.9^{1}$ & $0.2^{\mathrm{ns}}$ & $0.3^{\mathrm{ns}}$ \\
\hline \multirow{3}{*}{$\begin{array}{c}L . \\
\text { esculentum }\end{array}$} & SS & $41.8 \pm$ & $0.5 \pm 0.2 \mathrm{a}$ & $36.4 \pm 5.8 b$ & $5.8 \pm 0.7 \mathrm{ab}$ & $9.6 \pm 1.2 \mathrm{abc}$ & $46.3 \pm 2.5 \mathrm{a}$ \\
\hline & $\mathrm{RS}$ & $29.1 \pm 1.9 \mathrm{a}$ & $1.5 \pm 0.3 \mathrm{~cd}$ & $45.1 \pm 8.2 \mathrm{~d}$ & $5.9 \pm 0.9 \mathrm{ab}$ & $13.3 \pm 1.5 \mathrm{ab}$ & $46.8 \pm 4.2 b$ \\
\hline & alue & 15.0 & $2.8 *$ & $2.0^{\prime}$ & $0.2^{\mathrm{ns}}$ & $7.4 * * *$ & $0.2^{1}$ \\
\hline \multirow{3}{*}{ P. australis } & $S$ & & $1.6 \pm($ & $14.6 \pm$ & & $4.4 \pm$ & $33.2 \pm 1.2 \mathrm{a}$ \\
\hline & $\mathrm{RS}$ & $18.9 \pm 2.7 \mathrm{a}$ & $0.4 \pm 0.2 \mathrm{ab}$ & $8.9 \pm 0.2 \mathrm{a}$ & $1.4 \pm 0.3 \mathrm{a}$ & $13.9 \pm 2.0 \mathrm{ab}$ & $17.7 \pm 1.6 \mathrm{a}$ \\
\hline & $t$-value & $6.2 * * *$ & $2.7 *$ & $3.2 * *$ & $1.0^{\mathrm{ns}}$ & & $7.2 * * *$ \\
\hline \multirow{3}{*}{$\begin{array}{c}P . \\
\text { dioscoridis }\end{array}$} & $\mathrm{SS}$ & $27.8 \pm 3.2 \mathrm{ab}$ & $1.5 \pm 0.3 b$ & $18.0 \pm 3.9 \mathrm{a}$ & $4.4 \pm 0.7 \mathrm{ab}$ & $14.4 \pm 1.8 b c$ & $36.8 \pm 2.4 \mathrm{a}$ \\
\hline & RS & $17.7 \pm 3.9 \mathrm{a}$ & $1.2 \pm 0.3 \mathrm{abcd}$ & $19.9 \pm 2.3 \mathrm{ab}$ & $3.7 \pm 0.6 \mathrm{ab}$ & $13.4 \pm 2.3 \mathrm{ab}$ & $48.6 \pm 2.0 \mathrm{~b}$ \\
\hline & value & $7.0 * * *$ & $2.1^{\mathrm{ns}}$ & $1.2^{\mathrm{ns}}$ & $1.9^{\mathrm{ns}}$ & $1.1^{\mathrm{ns}}$ & $2.9 *$ \\
\hline \multirow{3}{*}{ P. oleracea } & & $48.2 \pm 2.9 c$ & $3.2 \pm 0.4 \mathrm{~d}$ & $27.5 \pm 4$ & $13.8 \pm 1.9 \mathrm{c}$ & $5.2 \pm 0$ & $80.2 \pm 10.1 \mathrm{c}$ \\
\hline & $\mathrm{RS}$ & $30.6 \pm 2.4 \mathrm{a}$ & $1.6 \pm 0.1 \mathrm{~d}$ & $17.5 \pm 2.8 \mathrm{ab}$ & $15.2 \pm 2.5 \mathrm{c}$ & $22.8 \pm 4.2 b$ & $51.8 \pm 6.5 b$ \\
\hline & $t$-value & $4.4 * *$ & $5.0 * *$ & $5.3 * *$ & $1.5^{\mathrm{ns}}$ & $4.8 * *$ & $6.4 * * *$ \\
\hline \multirow{3}{*}{$R$. dentatus } & $\mathrm{S}$ & $24.6 \pm 2.5 a$ & $1.6 \pm 0.3 b$ & $20.0 \pm 0.7 \mathrm{a}$ & $4.9 \pm 0.2 \mathrm{ab}$ & $18.8 \pm 0.6 c$ & $37.2 \pm 1.2 \mathrm{a}$ \\
\hline & $\mathrm{RS}$ & $19.5 \pm 5.2 \mathrm{a}$ & $1.3 \pm 0.3 \mathrm{bcd}$ & $15.9 \pm 1.0 \mathrm{ab}$ & $6.4 \pm 0.7 b$ & $26.3 \pm 4.2 b$ & $37.1 \pm 3.8 b$ \\
\hline & -value & $1.9^{\mathrm{ns}}$ & $0.7^{\mathrm{ns}}$ & $3.6 * *$ & $2.8 *$ & $1.7^{\mathrm{ns}}$ & $0.1^{\mathrm{ns}}$ \\
\hline \multirow{3}{*}{ S. nigrum } & SS & $31.8 \pm 5.2 \mathrm{ab}$ & $2.2 \pm 0.2 \mathrm{bcd}$ & $22.4 \pm 0.6 \mathrm{a}$ & $2.6 \pm 0.3 \mathrm{ab}$ & $2.8 \pm 0.4 a$ & $50.3 \pm 3.0 \mathrm{ab}$ \\
\hline & RS & $22.5 \pm 4.8 \mathrm{a}$ & $1.4 \pm 0.1 \mathrm{~cd}$ & $37.6 \pm 0.8 \mathrm{~cd}$ & $5.1 \pm 0.4 \mathrm{ab}$ & $6.1 \pm 0.1 \mathrm{a}$ & $51.4 \pm 3.3 b$ \\
\hline & -value & & $7.6 * * *$ & $19.3 * * *$ & $24.4 * * *$ & $10.3^{* * * *}$ & $1.1^{\mathrm{ns}}$ \\
\hline
\end{tabular}

$\mathrm{t}$-values represent the paired t-test. Means in the same columns (for each site) followed by different letters are significantly different at $\mathrm{p}<0.05$ according to Tukey HSD test. *: $\mathrm{p}<0.05, * *: \mathrm{p}<0.01, * * *$ : $\mathrm{p}<0.001$, ns: not significant (i.e., $\mathrm{p}>0.05$ )

Regarding the stoichiometric ratios, both SS and RS were only significantly different in $\mathrm{K} / \mathrm{Na}$ and $\mathrm{P} / \mathrm{K}$ ratios at $p<0.01$ (Table 4). For individual plant species, it was noticed that the following stochiometric ratios were significantly different among sites: $\mathrm{P} / \mathrm{K}$ in B. indica, $\mathrm{N} / \mathrm{P}$ and $\mathrm{K} / \mathrm{Na}$ in $A$. viridus, $\mathrm{N} / \mathrm{P}$ in $C$. bonarensis, $\mathrm{K} / \mathrm{Na}$ in $P$. australis. On the contrary, $S$. nigrum, $P$. dioscoridis and $L$. esculemtum showed no significant differences in the estimated stoichiometric ratios among sites. 

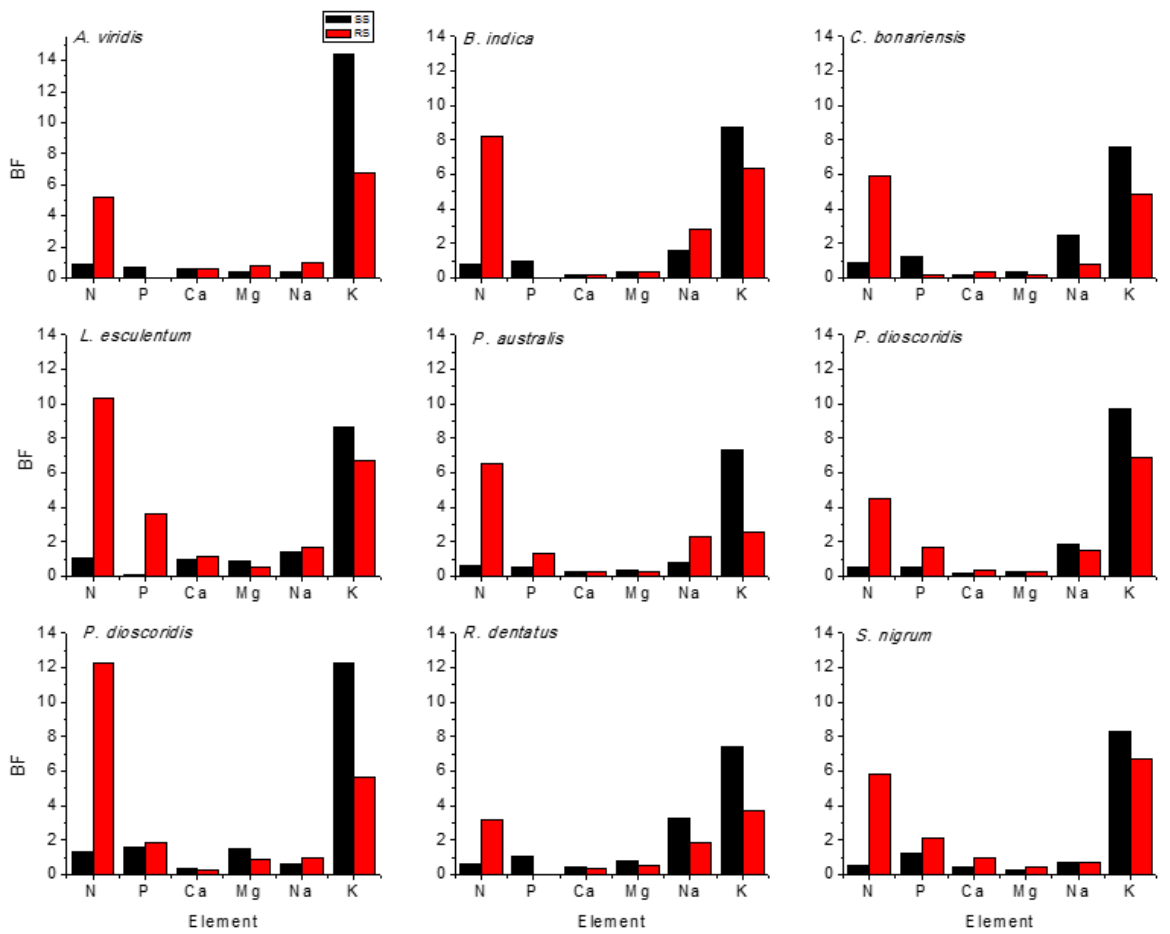

Figure 2. Mean ( $n=3)$ of bioaccumulation factors (BFs) from soil to below-ground tissues of macro-nutrients in nine native plant species that grown at sewage sludge dump site (SS) and reference site $(R S)$ in north Nile Delta, Egypt
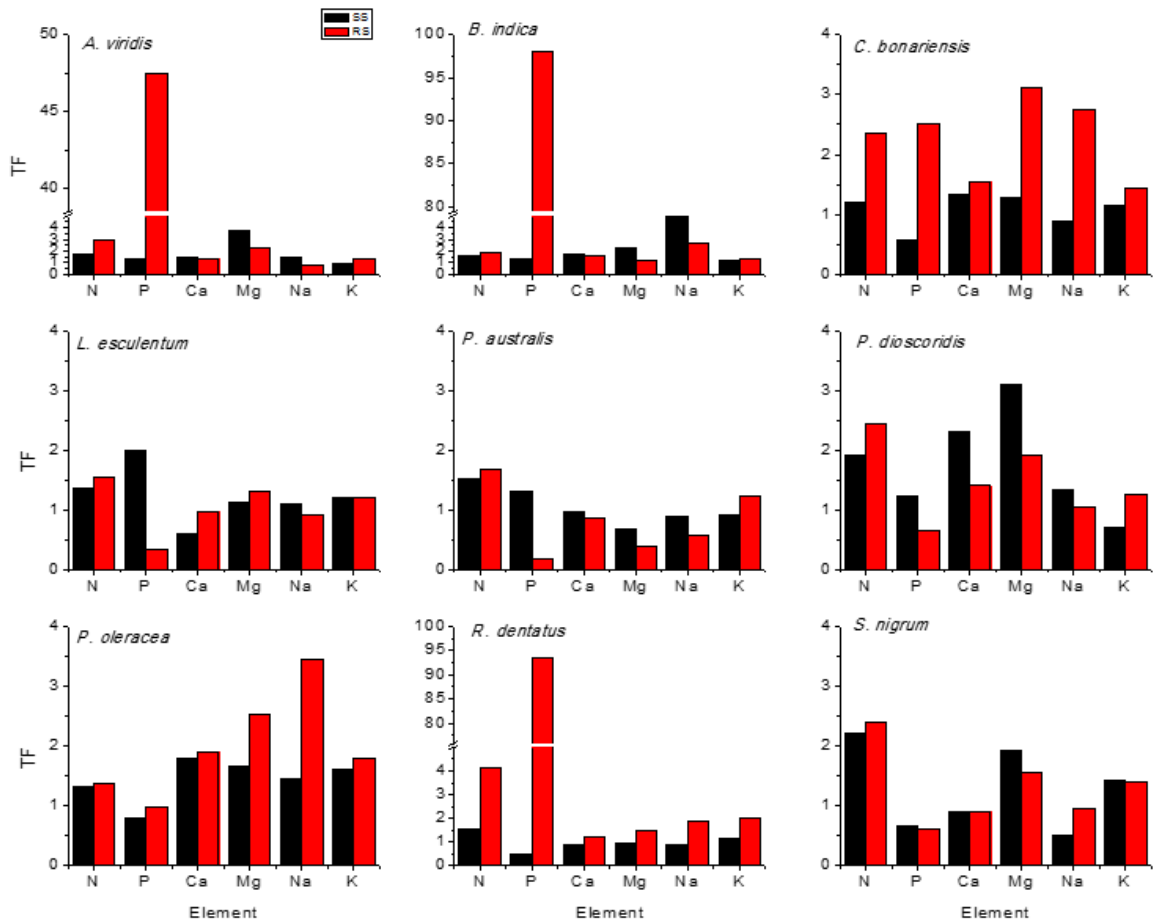

Figure 3. Mean $(n=3)$ of translocation factors $(T F s)$ from below-to above-ground tissues of macro-nutrients in nine native plant species that grown at sewage sludge dump site (SS) and reference site (RS) in north Nile Delta, Egypt 


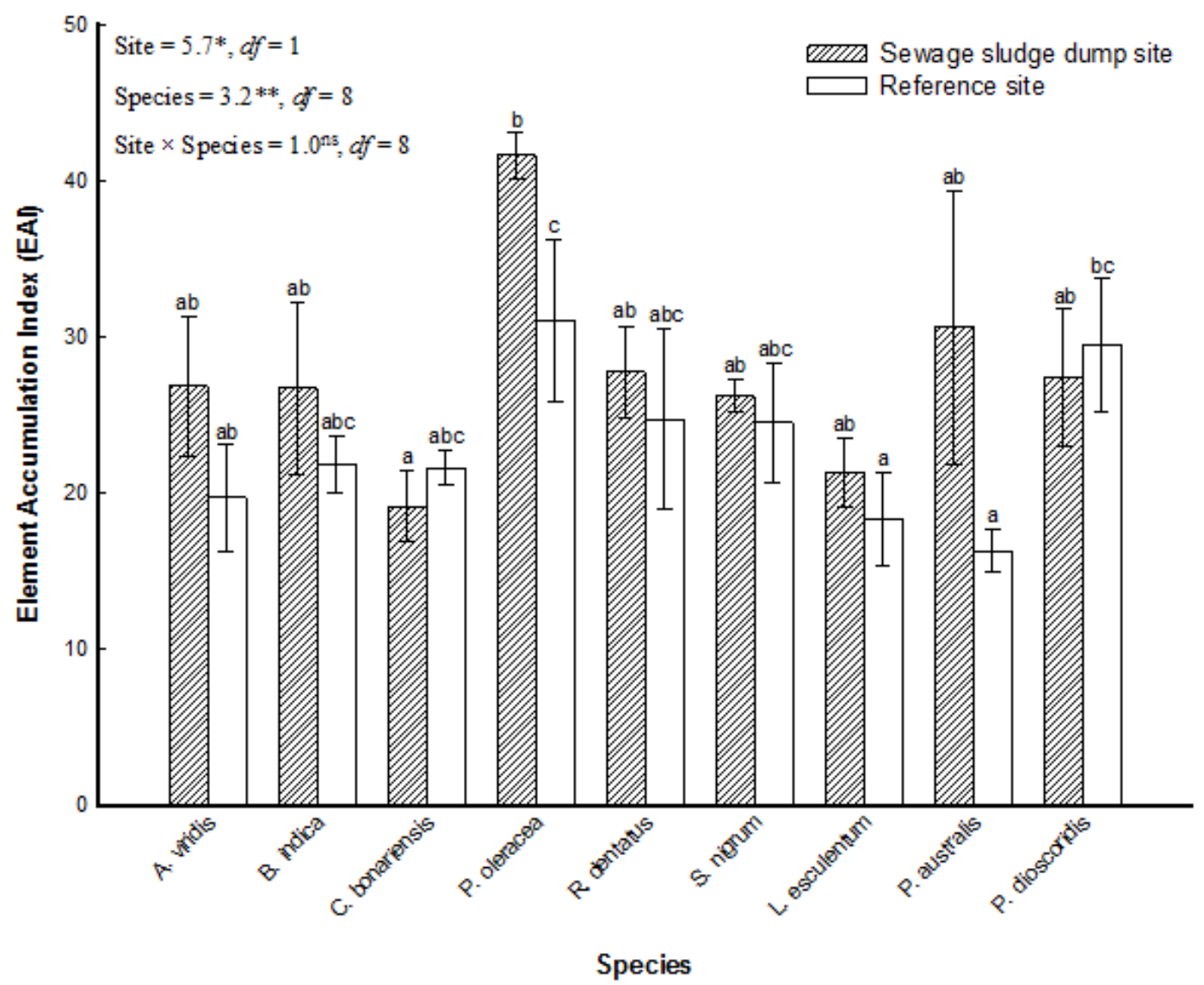

Figure 4. Element accumulation index (EAI) in nine native plant species that grown at sewage sludge dump site and reference site in north Nile Delta, Egypt. Site: Sewage sludge dump site/Reference site, Species: 9 native plant species, *: $p<0.05$, **: $p<0.01$, ns: not significant (i.e., $p>0.05$ ), df: degree of freedom. Means followed by different letters are significantly different at $p<0.05$ according to Tukey HSD test

\section{Discussion}

The collected soil from the SS was characterized by a higher $\mathrm{N}$ concentration than the RS, which could be ascribed to the high organic matter in its contents. The present study showed that the tissues of the studied plant species were characterized by high macro-nutrient concentrations at the SS more than at the soil of agricultural farms (control). This could be ascribed to the low $\mathrm{pH}$ value of the $\mathrm{SS}$ and its high concentrations of these elements. The results of some previous investigations indicated that the land application of sewage sludge increased soil $\mathrm{N}$ and $\mathrm{P}$ content (Bai et al., 2012), and plant uptake of $\mathrm{N}$ and $\mathrm{P}$ (Andres et al., 2010).

The uptake of macro-nutrients by plants varies among species and depends on the macro-nutrient demands of each species to apply their physiological and biochemical requirements. Plants differ both in their capacity to acquire macro-nutrients from the soil and in the amount of macro-nutrients they need per unit growth, the macro-nutrient concentrations in their tissue, and the time and extent to which they withdraw macronutrients during leaf senescence before leaf abscission (Kabata-Pendias, 2011). Lambers et al. (2008) reported that plants differ in the concentration of macro-nutrients in their 
tissue, depending on environment, allocation to woody and herbaceous tissues, developmental stage, and species. Moreover, N, P, and K are the macro-nutrients that most frequently limit plant growth. However, $\mathrm{N}$ tends to limit plant productivity on young soils, whereas $\mathrm{P}$ becomes increasingly limiting as soils age. The presence of high concentrations of $\mathrm{N}, \mathrm{P}, \mathrm{Ca}$ and $\mathrm{K}$ in the sampled plants from the SS compared to control site because these elements are essential for the plant growth. However, the presence of a specific mineral in plant tissues does not imply that the plant needs this mineral for growth. For example, high $\mathrm{Na}$ concentrations are not required for growth (Lambers et al., 2008).

Table 4. Stoichiometric ratios ( \pm standard deviations) of the studied nine plant species that grown at sewage sludge dump site (SS) and reference site (RS) in north Nile Delta, Egypt.

Bold values of the ratios in each column are significantly different among sites at $p<0.05$.

$F$-values and significance level are shown for each column

\begin{tabular}{c|c|c|c|c|c|c}
\hline Species & Site & $\mathbf{C a} / \mathbf{M g}$ & $\mathbf{N} / \mathbf{P}$ & $\mathbf{K} / \mathbf{N a}$ & $\mathbf{N} / \mathbf{K}$ & $\mathbf{P} / \mathbf{K}$ \\
\hline \multirow{2}{*}{ A. viridus } & SS & $9.1 \pm 5.0$ & $\mathbf{2 0 . 5} \pm \mathbf{3 . 1}$ & $\mathbf{2 0 . 4} \pm \mathbf{7 . 6}$ & $0.7 \pm 0.6$ & $0.04 \pm 0.02$ \\
& RS & $2.8 \pm 0.9$ & $\mathbf{7 3 . 1} \pm \mathbf{2 8 . 8}$ & $\mathbf{7 . 2} \pm \mathbf{2 . 4}$ & $0.6 \pm 0.5$ & $0.01 \pm 0.01$ \\
\hline \multirow{2}{*}{ B. indica } & SS & $4.3 \pm 0.7$ & $12.1 \pm 4.4$ & $2.0 \pm 1.9$ & $0.8 \pm 0.6$ & $\mathbf{0 . 1} \pm \mathbf{0 . 0 2}$ \\
& RS & $3.6 \pm 1.2$ & $41.2 \pm 6.7$ & $1.0 \pm 0.5$ & $0.5 \pm 0.2$ & $\mathbf{0 . 0 1} \pm \mathbf{0 . 0}$ \\
\hline \multirow{2}{*}{ C. bonariensis } & SS & $5.1 \pm 0.6$ & $\mathbf{1 7 . 7} \pm \mathbf{9 . 4}$ & $2.9 \pm 0.7$ & $0.7 \pm 0.2$ & $0.05 \pm 0.03$ \\
& RS & $6.9 \pm 3.0$ & $\mathbf{9 5 . 3} \pm \mathbf{2 1 . 8}$ & $3.4 \pm 1.6$ & $0.6 \pm 0.3$ & $0.01 \pm 0.0$ \\
\hline \multirow{2}{*}{ L. esculentum } & SS & $5.8 \pm 3.1$ & $183.2 \pm 6.7$ & $6.0 \pm 4.0$ & $0.9 \pm 0.3$ & $0.01 \pm 0.0$ \\
& RS & $6.8 \pm 3.4$ & $40.3 \pm 6.5$ & $4.6 \pm 1.0$ & $0.7 \pm 0.4$ & $0.04 \pm 0.0$ \\
\hline \multirow{2}{*}{ P. australis } & SS & $7.8 \pm 2.1$ & $17.4 \pm 11.3$ & $\mathbf{7 . 6} \pm \mathbf{0 . 3}$ & $0.8 \pm 0.6$ & $0.05 \pm 0.01$ \\
& RS & $7.5 \pm 2.8$ & $10.9 \pm 0.0$ & $\mathbf{1 . 8} \pm \mathbf{1 . 7}$ & $1.0 \pm 0.2$ & $0.03 \pm 0.01$ \\
\hline \multirow{2}{*}{ P. dioscoridis } & SS & $4.1 \pm 1.6$ & $24.3 \pm 17.5$ & $2.9 \pm 1.3$ & $0.8 \pm 0.5$ & $0.04 \pm 0.0$ \\
& RS & $5.7 \pm 1.1$ & $26.5 \pm 5.5$ & $5.0 \pm 3.8$ & $0.4 \pm 0.2$ & $0.02 \pm 0.0$ \\
\hline \multirow{2}{*}{ P. oleracea } & SS & $1.9 \pm 0.2$ & $18.3 \pm 2.8$ & $17.0 \pm 9.7$ & $0.6 \pm 0.1$ & $0.05 \pm 0.01$ \\
& RS & $1.2 \pm 0.3$ & $18.7 \pm 3.9$ & $2.8 \pm 1.4$ & $0.7 \pm 0.3$ & $0.04 \pm 0.02$ \\
\hline \multirow{2}{*}{ R. dentatus } & SS & $4.1 \pm 0.4$ & $29.2 \pm 4.5$ & $2.0 \pm 0.3$ & $0.7 \pm 0.3$ & $0.04 \pm 0.0$ \\
& RS & $2.6 \pm 0.4$ & $31.3 \pm 9.1$ & $1.5 \pm 0.3$ & $0.5 \pm 0.3$ & $0.03 \pm 0.0$ \\
\hline \multirow{2}{*}{ S. nigrum } & SS & $9.8 \pm 4.9$ & $15.5 \pm 8.1$ & $21.3 \pm 10.4$ & $0.6 \pm 0.3$ & $0.05 \pm 0.0$ \\
& RS & $7.9 \pm 2.7$ & $17.3 \pm 11.6$ & $8.5 \pm 2.2$ & $0.4 \pm 0.02$ & $0.03 \pm 0.0$ \\
\hline F-value & & 0.7 & 0.001 & 7.7 & 3.2 & 8.5 \\
p & & 0.4 & 0.9 & $\mathbf{0 . 0 0 8}$ & 0.08 & $\mathbf{0 . 0 0 5}$ \\
\hline
\end{tabular}

The presence of high macro-nutrients concentrations in leaves compared to the other tissues because leaves are the main sink for minerals in plants. Macro-nutrients associated with metabolism (e.g., N, P, and K) have their highest concentrations when a leaf or other tissue is first produced, then concentrations decline by dilution during cell wall formation and then by resorption of macro-nutrients during senescence, while the roots have intermediate concentrations. Species differ in the macro-nutrient requirement for growth but the physiological mechanisms for this are not always known (Woodward et al., 1984). The variations in macro-nutrient concentrations in various parts of plants have been ascribed to compartmentalization and translocation through the vascular 
system (Kim et al., 2003). As stem plays the role of a transferring tissue, minimum concentrations of macro-nutrients were found in stem (Planquart et al., 1999).

The evaluation of the bioaccumulation factor $(\mathrm{BF})$ represents a simple method to characterize quantitatively the transfer of available macro-nutrients from the soil to the plant (Branzini et al., 2012; Farahat et al., 2017), while its ability to translocate them from the roots to the shoots is measured using the translocation factor (TF). Both BF and TF can be used to estimate a plant's potential for phytoremediation purposes (Galal and Shehata, 2015). According to $\mathrm{Zu}$ et al. (2005), BF > 1.0 were found in macronutrient- and heavy metal-accumulating plants, whereas they were typically $<1.0$ in macro-nutrient- and heavy metal-excluding plants. TF $>1.0$ indicate that the plant is effective in the translocation of macro-nutrients from root to shoot tissue (Ma et al., 2001). In the present study, all studied species were characterized by BF values $>1.0$ for some of the macro-nutrients, showing that they can accumulate macro-nutrients and are therefore more suitable for phytoextraction purposes. In the present study, the accumulation of macro-nutrients was done regardless of their stem size or life form of the species. For instance, $P$. oleracea as short $(20-40 \mathrm{~cm})$ annual herbaceous plant tend to accumulate high concentrations of $\mathrm{N}, \mathrm{P}$ and $\mathrm{K}$ more than other perennial tall species e.g., $P$. dioscoridis and $P$. australis. The same observations were reported by Farahat and Linderholm (2013) for medicinal native plants that irrigated by sewage wastewater. Although the BF values for some macro-nutrients were $>1.0$, which means that our study species could accumulate these macro-nutrients, but none of them are hyperaccumulator (Kabata-Pendias, 2011).

The presence of $\mathrm{TF}$ values $>1.0$ for $\mathrm{N}, \mathrm{P}, \mathrm{Ca}, \mathrm{Mg}$, and $\mathrm{K}$ mean that plants allocate the macro-nutrients in their vegetative parts because it is essential for growth. This behavior is opposite in many cases to the TF values for heavy metals that estimated in many aquatic and terrestrial plants (e.g., Galal and Farahat, 2015; Galal and Shehata, 2015; Eid et al., 2018a). This could be attributed to the fact that macro-nutrients are more essential for plant growth than heavy metals (Lambers et al., 2008). As a rule, when a plant has TF value $>1.0$ for a certain mineral, this indicates the its suitability for the phytoextraction of this mineral, while $\mathrm{TF}$ value $<1.0$ indicates its suitability for the phytostabilization of this mineral. For instance, A. viridus and B. indica are good phytoextractor for $\mathrm{N}, \mathrm{P}, \mathrm{Ca}, \mathrm{Mg}$ and $\mathrm{Na}$

Plant species accumulate different elements simultaneously, so the element accumulation index (EAI) was used to assess the overall performance of macro-nutrient accumulation in the studied plant species. Thus, in the present study, the highest EAI values of $P$. oleracea, $P$. australis, $R$. dentatus, $P$. dioscoridis, $A$. viridis and $B$. indica from the SS; and $P$. oleracea, $P$. dioscoridis, $R$. dentatus and $S$. nigrum from the cultivated field soil, indicates that these species are better able to accumulate macronutrients, and are therefore more suitable for phytoextraction purposes.

The stoichiometric ratios vary among species and depends on many limiting factors. For instance, $\mathrm{N}: \mathrm{P}$ ratios are, on average, higher in graminoids than in forbs and higher in stress-tolerant species than in ruderals. This ratio declines with increasing growth rates (Lambers et al., 2008). The whole-plant biomass N:P ratios may vary up to 50fold, due to differences in macro-nutrient uptake, biomass turnover, root allocation, and reproductive output (Aerts and Chapin, 2000). In the present study, there were few ratios that are significantly different among sites and species. In our opinion the availability of water and macro-nutrients in the studied sites interacts differently according to the species. This agrees with the findings of Lü et al. (2012) and Farahat 
and Linderholm (2015). They reported that in rich $\mathrm{N}$ habitats, water availability can modulate the plant nutritional and stoichiometric responses to increased $\mathrm{N}$ and other macro-nutrients.

The present study proved that the concentrations of all macro-nutrients (except K) in the tissues of the most studied plant species were positively correlated with those in the soil. Such correlations indicate that these species reflect the cumulative effects of environmental pollution from the soil, and thereby suggesting their potential use in the biomonitoring of most macro-nutrients examined. This indication is supported by several studies according to which the total quantity of some macro-nutrients in a soil is correlated with the quantity of macro-nutrients absorbed by plants (Bonanno, 2011, 2013; Bonanno and Lo Giudice, 2010; Eid et al., 2012a, b; Eid and Shaltout, 2014). Moreover, plants with macro-nutrient concentrations strongly correlated with those in the soil have been considered potential indicators of macro-nutrient availability (Alyemeni and Almohisen, 2014).

\section{Conclusion and recommendations}

In this study, it was found that some plant species were more effective in absorbing certain macro-nutrients compared to other species that grown in the same soil. $L$. esculentum can bioaccumulate many of the macro-nutrients from sewage sludge without excessive quantities of macro-nutrients being translocated into the edible portions of the plant (fruits). In the present study, establishing a pattern of translocation of macronutrients from root to shoot of a plant can be very useful in biological monitoring of macro-nutrient contamination as well as a selection of macro-nutrient accumulator species. The highest EAI values of $P$. oleracea, $P$. australis, $R$. dentatus, $P$. dioscoridis, $A$. viridis and $B$. indica growing in the $\mathrm{SS}$; and of $P$. oleracea, $P$. dioscoridis, $R$. dentatus and $S$. nigrum growing in the cultivated field soil, indicate that they are better able to accumulate macro-nutrients and are therefore more suitable for phytoextraction purposes.

Due to the noticeable high concentrations of macro-nutrients in the different tissues of the studied species, we recommend it in mitigation of the eutrophic status of SS when applied to the agricultural lands. This will be achieved through leaving these weeds grow prior to cultivation of the agricultural crops. This needs further investigation to determine the best density for each native species that helps efficiently in reducing the macro-nutrients load of sewage sludge on the cultivated plants.

Acknowledgements. This work was supported by the Deanship of Scientific Research at King Khalid University under Grant number R.G.P. 1/94/40.

\section{REFERENCES}

[1] Aerts, R., Chapin, F. S. (2000): The mineral nutrition of wild plants revisited: a reevaluation of processes and patterns. - Advanced Ecological Research 30: 1-67.

[2] Allen, S. (1989): Chemical Analysis of Ecological Materials. - Blackwell Scientific Publications, London.

[3] Alyemeni, M. N., Almohisen, I. A. A. (2014): Traffic and industrial activities around Riyadh cause the accumulation of heavy metals in legumes: a case study. - Saudi Journal of Biological Science 21: 167-172. 
[4] Andres, E. F., Tenorio, J. L., Walter, I. (2010): Biomass production and nutrient concentration of kenaf grown on sewage sludge-amended soil. - Spanish Journal of Agriculture Research 8: 472-480.

[5] Antolín, C. M., Muro, I., Sánchez-Díaz, M. (2010): Application of sewage sludge improves growth, photosynthesis and antioxidant activities of nodulated alfalfa plants under drought conditions. - Environmental and Experimental Botany 68: 75-82.

[6] APHA (1998): Standard Methods for the Examination of Water and Wastewater. American Public Health Association, Washington, DC.

[7] Aráujo, A. S. F., Monteiro, R. T. R., Carvalho, E. M. S. (2007): Effects of composted textile nodulation and nitrogen fixation of soybean and cowpea. - Bioresource Technology 98: 1028-1032.

[8] Bai, Y. C., Wang, L., Tao, T. Y., Chen, G. H., Qian, X. Q., Feng, K., Shan, Y. H. (2012): Study on the amendment of physicochemical properties of tidal flat soil by sewage sludge application. - Plant Nutrition and Fertilizer Science 18: 1019-1025.

[9] Bonanno, G. (2011): Trace element accumulation and distribution in the organs of Phragmites australis (common reed) and biomonitoring applications. - Ecotoxicology and Environmental Safety 74: 1057-1064.

[10] Bonanno, G. (2013): Comparative performance of trace element bioaccumulation and biomonitoring in the plant species Typha domingensis, Phragmites australis and Arundo donax. - Ecotoxicology and Environmental Safety 97: 124-130.

[11] Bonanno, G., Lo Giudice, R. (2010): Heavy metal bioaccumulation by the organs of Phragmites australis (common reed) and their potential use as contamination indicators. - Ecological Indicators 10: 639-645.

[12] Boulos, L. (1999): Flora of Egypt. Vol. 1 (Azollaceae - Oxalidaceae). - Al-Hadara Publishing, Cairo.

[13] Boulos, L. (2002): Flora of Egypt. Vol. 3 (Verbenaceae - Compositae). - Al-Hadara Publishing, Cairo.

[14] Boulos, L. (2005): Flora of Egypt. Vol. 4. Monocotyledons, (Alismataceae Orchidaceae). - Al-Hadara Publishing, Cairo.

[15] Branzini, A., González, R. S., Zubillaga, M. (2012): Absorption and translocation of copper, zinc and chromium by Sesbania virgata. - Journal of Environmental Management 102: 50-54.

[16] Chandra, R., Yadav, S., Yadav, S. (2017): Phytoextraction potential of heavy metals by native wetland plants growing on chlorolignin containing sludge of pulp and paper industry. - Ecological Engineering 98: 134-145.

[17] Eid, E. M., Alamri, S. A. M., Shaltout, K. H., Galal, T. M., Ahmed, M. T., Brima, E. I., Sewelam, N. (2020c): A sustainable food security approach: Controlled land application of sewage sludge recirculates nutrients to agricultural soils and enhances crop productivity. - Food and Energy Security (accepted).

[18] Eid, E. M., Alrumman, S. A., El-Bebany, A. F., Fawy, K. F., Taher, M. A., Hesham, A., El-Shaboury, G. A., Ahmed, M. T. (2018b): The evaluation of sewage sludge application as a fertilizer for broad bean (Faba sativa Bernh.) crops. - Food and Energy Security 7: $\mathrm{e} 00142$.

[19] Eid, E. M., Alrumman, S. A., El-Bebany, A. F., Fawy, K. F., Taher, M. A., Hesham, A., El-Shaboury, G. A., Ahmed, M. T. (2019): Evaluation of the potential of sewage sludge as a valuable fertilizer for wheat (Triticum aestivum L.) crops. - Environmental Science and Pollution Research 26: 392-401.

[20] Eid, E. M., Alrumman, S. A., El-Bebany, A. F., Hesham, A., Taher, M. A., Fawy, K. F. (2017b): The effects of different sewage sludge amendment rates on the heavy metal bioaccumulation, growth and biomass of cucumbers (Cucumis sativus L.). Environmental Science and Pollution Research 24: 16371-16382.

[21] Eid, E. M., Alrumman, S. A., Farahat, E. A., El-Bebany, A. F. (2018a): Prediction models for evaluating the uptake of heavy metals by cucumbers (Cucumis sativus L.) grown in 
agricultural soils amended with sewage sludge. - Environmental Monitoring and Assessment 190: 501.

[22] Eid, E. M., El-Bebany, A. F., Alrumman, S. A., Hesham, A., Taher, M. A., Fawy, K. F. (2017a): Effects of different sewage sludge applications on heavy metal accumulation, growth and yield of spinach (Spinacia oleracea L.). - International Journal of Phytoremediation 19: 340-347.

[23] Eid, E. M., El-Bebany, A. F., Taher, M. A., Alrumman, S. A., Hussain, A. A., Galal, T. M., Shaltout, K. H., Sewelam, N. A., Ahmed, M. T., El-Shaboury, G. A. (2020b): Influences of sewage sludge-amended soil on heavy metal accumulation, growth and yield of rocket plant (Eruca sativa). - Applied Ecology and Environmental Research (accepted).

[24] Eid, E. M., El-Sheikh, M. A., Alatar, A. A. (2012b): Uptake of Ag, Co and Ni by the organs of Typha domingensis (Pers.) Poir. ex Steud. in Lake Burullus and their potential use as contamination indicators. - Open Journal of Modern Hydrology 2: 21-27.

[25] Eid, E. M., Hussain, A. A., Taher, M. A., Galal, T. M., Shaltout, K. H., Sewelam, N. (2020a): Sewage sludge application enhances the growth of Corchorus olitorius plants and provides a sustainable practice for nutrient recirculation in agricultural soils. Journal of Soil Science and Plant Nutrition 20: 149-159.

[26] Eid, E. M., Shaltout, K. H. (2014): Monthly variations of trace elements accumulation and distribution in above- and below-ground biomass of Phragmites australis (Cav.) Trin. ex Steudel in Lake Burullus (Egypt): a biomonitoring application. - Ecological Engineering 73: 17-25.

[27] Eid, E. M., Shaltout, K. H. (2016): Bioaccumulation and translocation of heavy metals by nine native plant species grown at a sewage sludge dump site. - International Journal of Phytoremediation 18: 1075-1085.

[28] Eid, E. M., Shaltout, K. H., Al-Sodany, Y. M., Jensen, K. (2010): Effects of abiotic conditions on Phragmites australis along geographic gradients in Lake Burullus, Egypt. Aquatic Botany 92: 86-92.

[29] Eid, E. M., Shaltout, K. H., El-Sheikh, M. A., Asaeda, T. (2012a): Seasonal courses of nutrients and heavy metals in water, sediment and above- and below-ground Typha domingensis biomass in Lake Burullus (Egypt): perspective for phytoremediation. - Flora 207: 783-794.

[30] El-Sheikh, M. A., Al-Sodany, Y. M., Eid, E. M., Shaltout, K. H. (2012): Ten years primary succession on a newly created landfill at a lagoon of the Mediterranean Sea (Lake Burullus RAMSAR site). - Flora 207: 459-468.

[31] EMA (1980): Climatic Normals for the Arab Republic of Egypt up to 1975. - Ministry of Civil Aviation, Egyptian Meteorological Authority, General Organization for Governmental Printing Offices, Cairo.

[32] Farahat, E. A., Galal, T., Elawa, O., Hassan, L. M. (2017): Health risk assessment and growth characteristics of wheat and maize crops irrigated with contaminated wastewater. - Environmental Monitoring and Assessment 189: 535.

[33] Farahat, E. A., Linderholm, H. W. (2013): Effects of treated wastewater irrigation on size-structure, biochemical products and mineral content of native medicinal shrubs. Ecological Engineering 60: 235-241.

[34] Farahat, E. A., Linderholm, H. W. (2015): Nutrient resorption efficiency and proficiency in economic wood trees irrigated by treated wastewater in desert planted forests. Agriculture Water Management 155: 67-75.

[35] Fuentes, D., Valdecantos, A., Cortina, J., Vallejo, V. R. (2007): Seedling performance in sewage sludge-amended degraded Mediterranean woodlands. - Ecological Engineering 31: 281-291.

[36] Galal, T. M. (2016): Health hazards and heavy metals accumulation by summer squash (Cucurbita pepo L.) cultivated in contaminated soils. - Environmental Monitoring and Assessment 188: 434. 
[37] Galal, T. M., Farahat, E. (2015): The invasive macrophyte Pistia stratiotes L. as a bioindicator and a biomonitor for water pollution in Lake Mariut, Egypt. - Environmental Monitoring and Assessment 187: 701-711.

[38] Galal, T. M., Shehata, H. S. (2015): Bioaccumulation and translocation of heavy metals by Plantago major L. grown in contaminated soils under the effect of traffic pollution. Ecological Indicators 48: 244-251.

[39] Gupta, S., Nayek, S., Saha, R. N., Satpati, S. (2008): Assessment of heavy metal accumulation in macrophyte, agricultural soil and crop plants adjacent to discharge zone of sponge iron factory. - Environmental Geology 55: 731-739.

[40] Henry, C. L., Cole, D. W., Harrison, R. B. (1994): Use of municipal sludge to restore and improve site productivity in forestry: the pack forest sludge research program. - Forest Ecology and Management 66: 137-149.

[41] Ho, Y. B., Wong, W. (1994): Growth and macronutrient removal of water hyacinth in a small secondary sewage treatment plant. - Resources, Conservation and Recycling 11: 161-178.

[42] Kabata-Pendias, A. (2011): Trace Elements in Soils and Plants. - CRC Press, Boca Raton, FL.

[43] Kim, I. S., Kang, H. K., Johnson-Green, P., Lee, E. J. (2003): Investigation of heavy metal accumulation in Polygonum thunbergii for phytoextraction. - Environmental Pollution 126: 235-243.

[44] Korboulewskya, N., Bonina, G., Massiani, C. (2002): Biological and ecophysiological reactions of white wall rocket (Diplotaxis erucoides L.) grown on sewage sludge compost. - Environmental Pollution 117: 365-370.

[45] Lambers, H., Stuart Chapin III, F., Pons, T. L. (2008): Plant Physiological Ecology. Second Ed. - Springer-Verlag, New York.

[46] Liu, Y. J., Zhu, Y. G., Ding, H. (2007): Lead and cadmium in leaves of deciduous trees in Beijing, China: development of a metal accumulation index (MAI). - Environmental Pollution 145: 387-390.

[47] Lü, X. T., Kong, D. L., Pan, Q. M., Simmons, M. E., Han, X. G. (2012): Nitrogen and water availability interact to affect leaf stoichiometry in a semi-arid grassland. Oecologia 168: 301-310.

[48] Ma, L. Q., Komar, K. M., Tu, C., Zhang, W., Cai, Y., Kennelley, E. D. (2001): A fern that hyperaccumulates arsenic. - Nature 409: 579.

[49] Moreno-Caselles, J., Pérez-Murcia, M. D., Pérez-Espinosa, A., Moral, R. (1997): Heavy metal pollution in sewage sludges and agricultural impact. - Fresenius Environmental Bulletin 6: 519-524.

[50] Peng, K., Luo, C., Lou, L., Li, X., Shen, Z. (2008): Bioaccumulation of heavy metals by the aquatic plants Potamogeton pectinatus L. and Potamogeton malaianus Miq. and their potential use for contamination indicators and in wastewater treatment. - Science of the Total Environment 392: 22-29.

[51] Planquart, P., Bonin, G., Prone, A., Massiani, C. (1999): Distribution, movement and plant availability of trace metals in soils amended with sewage sludge compost: application to low metal loading. - Science of the Total Environment 241: 161-179.

[52] Quilbé, R., Serreau, C., Wicherek, S., Bernard, C., Thomas, Y., Oudinet, J.-P. (2005): Nutrient transfer by runoff from sewage sludge amended soil under simulated rainfall. Environmental Monitoring and Assessment 100: 177.

[53] Shaltout, K. H., El-Hamdi, K. H., El-Masry, S. A., Eid, E. M. (2019): Bedouin farms in the Saint Katherine mountainous area (South Sinai, Egypt). - Journal of Mountain Science 16: 2232-2242.

[54] Singh, R. P., Agrawal, M. (2007): Effects of sewage sludge amendment on heavy metal accumulation and consequent responses of Beta vulgaris plants. - Chemosphere 67: 2229-2240. 
[55] Singh, R. P., Agrawal, M. (2010): Variations in heavy metal accumulation, growth and yield of rice plants grown at different sewage sludge amendment rates. - Ecotoxicology and Environmental Safety 73: 632-641.

[56] Statsoft (2007): Statistica Version 7.1. - Statsoft Inc: Tulsa, OK.

[57] Wilke, B. M. (2005): Determination of Chemical and Physical Soil Properties. In: Margesin, R., Schinner, F. (eds.) Manual for Soil Analysis - Monitoring and Assessing Soil Bioremediation. - Springer-Verlag, Heidelberg, pp. 47-95.

[58] Woodward, R. A., Harper, K. T., Tiedemann, A. R. (1984): An ecological consideration of the significance of cation exchange capacity of roots of some Utah range plants. Plant and Soil 79: 169-180.

[59] Xiao, R., Bai, J., Zhang, H., Gao, H., Liua, X., Wilkes, A. (2011): Changes of P, Ca, Al and $\mathrm{Fe}$ contents in fringe marshes along a pedogenic chronosequence in the Pearl River estuary, South China. - Continuous Shelf Research 31: 739-747.

[60] Yu, S., Chen, W., He, X., Liu, Z., Huang, Y. (2014): Biomass accumulation and nutrient uptake of 16 riparian woody plant species in Northeast China. - Journal of Forestry Research 25: 773-778.

[61] Zhao, Y., Xia, X., Yang, Z. (2013): Growth and nutrient accumulation of Phragmites australis in relation to water level variation and nutrient loadings in a shallow lake. Journal of Environmental Sciences 25: 16-25.

[62] Zu, Y. Q., Li, Y., Chen, J. J., Chen, H. Y., Qin, L., Schvartz, C. (2005): Hyperaccumulation of $\mathrm{Pb}, \mathrm{Zn}$ and $\mathrm{Cd}$ in herbaceous grown on lead-zinc mining area in Yunnan, China. - Environment International 31: 755-762. 


\section{APPENDIX}

Appendix 1. Macro-nutrient concentrations \pm standard errors in nine native plant species grown at sewage sludge dump site (SS) and reference site (RS) in north Nile Delta, Egypt

\begin{tabular}{|c|c|c|c|c|c|c|c|c|}
\hline \multirow{2}{*}{ Species } & \multirow{2}{*}{ Site } & \multirow{2}{*}{ Tissue } & \multicolumn{6}{|c|}{ Macro-nutrient $\left(\mathrm{mg} \mathrm{g}^{-1}\right)$} \\
\hline & & & $\mathbf{N}$ & $\mathbf{P}$ & $\mathbf{C a}$ & Mg & $\mathbf{N a}$ & $\mathbf{K}$ \\
\hline \multirow{9}{*}{ A. viridis } & \multirow{4}{*}{ SS } & $\mathrm{L}(n=3)$ & $57.5 \pm 0.7$ & $2.6 \pm 0.0$ & $51.9 \pm 0.9$ & $12.2 \pm 0.2$ & $3.4 \pm 0.1$ & $41.2 \pm 0.7$ \\
\hline & & $\mathrm{S}(n=3)$ & $38.1 \pm 0.7$ & $1.7 \pm 0.0$ & $39.1 \pm 0.8$ & $4.5 \pm 0.1$ & $4.0 \pm 0.1$ & $88.0 \pm 2.3$ \\
\hline & & $\mathrm{R}(n=3)$ & $27.0 \pm 0.2$ & $1.6 \pm 0.0$ & $31.3 \pm 0.5$ & $2.2 \pm 0.0$ & $2.5 \pm 0.1$ & $67.5 \pm 1.5$ \\
\hline & & $M(n=9)$ & $40.9 \pm 4.5 \mathrm{bc}$ & $2.0 \pm 0.2 b c$ & $40.8 \pm 3.0 \mathrm{~b}$ & $6.3 \pm 1.5 b$ & $3.3 \pm 0.2 \mathrm{a}$ & $65.6 \pm 6.8 \mathrm{bc}$ \\
\hline & \multirow{4}{*}{$\mathrm{RS}$} & $\mathrm{L}(n=3)$ & $42.2 \pm 0.6$ & $0.8 \pm 0.0$ & $36.6 \pm 0.8$ & $16.6 \pm 0.3$ & $5.5 \pm 0.2$ & $36.9 \pm 0.4$ \\
\hline & & $\mathrm{S}(n=3)$ & $18.7 \pm 0.3$ & $0.2 \pm 0.0$ & $26.0 \pm 0.6$ & $11.6 \pm 0.2$ & $7.4 \pm 0.2$ & $72.2 \pm 3.3$ \\
\hline & & $\mathrm{R}(n=3)$ & $10.3 \pm 0.1$ & $0.0 \pm 0.0$ & $24.4 \pm 0.4$ & $6.2 \pm 0.1$ & $8.0 \pm 0.2$ & $40.7 \pm 0.9$ \\
\hline & & $M(n=9)$ & $23.7 \pm 4.8 \mathrm{a}$ & $0.3 \pm 0.1 \mathrm{ab}$ & $29.0 \pm 1.9 b c$ & $11.5 \pm 1.5 \mathrm{c}$ & $7.0 \pm 0.4 a$ & $49.9 \pm 5.7 b$ \\
\hline & & value & $22.2 * * *$ & $29.8 * * *$ & $9.3 * * *$ & $10.3 * * *$ & $7.4 * * *$ & $4.3 * *$ \\
\hline \multirow{9}{*}{ B. indica } & \multirow{4}{*}{ SS } & $\mathrm{L}(n=3)$ & $50.9 \pm 0.3$ & $3.0 \pm 0.0$ & $21.9 \pm 0.4$ & $6.3 \pm 0.1$ & $59.4 \pm 1.0$ & $34.1 \pm 0.6$ \\
\hline & & $\mathrm{S}(n=3)$ & $24.9 \pm 0.5$ & $2.9 \pm 0.0$ & $17.5 \pm 0.4$ & $4.0 \pm 0.1$ & $43.3 \pm 1.5$ & $57.6 \pm 1.5$ \\
\hline & & $\mathrm{R}(n=3)$ & $24.4 \pm 0.1$ & $2.3 \pm 0.0$ & $11.4 \pm 0.1$ & $2.3 \pm 0.0$ & $9.9 \pm 0.2$ & $41.1 \pm 1.0$ \\
\hline & & M $(n=9)$ & $33.4 \pm 4.4 a b$ & $2.8 \pm 0.1 \mathrm{~cd}$ & $16.9 \pm 1.5 \mathrm{a}$ & $4.2 \pm 0.6 \mathrm{ab}$ & $37.5 \pm 7.3 \mathrm{~d}$ & $44.3 \pm 3.5 \mathrm{a}$ \\
\hline & \multirow{4}{*}{$\mathrm{RS}$} & $\mathrm{L}(n=3)$ & $40.3 \pm 0.5$ & $0.6 \pm 0.0$ & $11.9 \pm 0.2$ & $3.9 \pm 0.1$ & $68.1 \pm 0.5$ & $51.1 \pm 1.6$ \\
\hline & & $\mathrm{S}(n=3)$ & $19.8 \pm 0.2$ & $1.3 \pm 0.0$ & $13.2 \pm 0.1$ & $2.7 \pm 0.0$ & $66.5 \pm 4.4$ & $50.2 \pm 1.1$ \\
\hline & & $\mathrm{R}(n=3)$ & $16.4 \pm 0.4$ & $0.0 \pm 0.0$ & $7.9 \pm 0.1$ & $2.9 \pm 0.0$ & $24.4 \pm 0.9$ & $38.1 \pm 1.1$ \\
\hline & & M $(n=9)$ & $25.5 \pm 3.7 \mathrm{a}$ & $0.7 \pm 0.2 \mathrm{abc}$ & $11.0 \pm 0.8 \mathrm{a}$ & $3.2 \pm 0.2 \mathrm{ab}$ & $53.0 \pm 7.3 \mathrm{c}$ & $46.5 \pm 2.2 b$ \\
\hline & & value & $9.1 * * *$ & $16.3 * * *$ & $5.7 * * *$ & $2.4 *$ & $6.6 * * *$ & $0.6^{\mathrm{ns}}$ \\
\hline \multirow{9}{*}{ C. bonariensis } & \multirow{4}{*}{ SS } & $\mathrm{L}(n=3)$ & $43.0 \pm 0.2$ & $2.6 \pm 0.2$ & $22.2 \pm 0.4$ & $4.7 \pm 0.1$ & $17.8 \pm 0.4$ & $48.0 \pm 1.3$ \\
\hline & & $\mathrm{S}(n=3)$ & $19.3 \pm 0.4$ & $0.7 \pm 0.0$ & $8.0 \pm 0.1$ & $1.4 \pm 0.0$ & $9.3 \pm 0.4$ & $33.4 \pm 0.9$ \\
\hline & & $\mathrm{R}(n=3)$ & $25.8 \pm 0.3$ & $2.9 \pm 0.2$ & $11.3 \pm 0.1$ & $2.4 \pm 0.1$ & $15.5 \pm 0.3$ & $35.7 \pm 0.9$ \\
\hline & & $M(n=9)$ & $29.4 \pm 3.5 \mathrm{ab}$ & $2.1 \pm 0.4 b c$ & $13.9 \pm 2.1 \mathrm{a}$ & $2.8 \pm 0.5 \mathrm{ab}$ & $14.2 \pm 1.3 \mathrm{bc}$ & $39.0 \pm 2.3 \mathrm{a}$ \\
\hline & \multirow{4}{*}{ RS } & $\mathrm{L}(n=3)$ & $38.0 \pm 0.9$ & $0.5 \pm 0.0$ & $21.4 \pm 0.2$ & $5.3 \pm 0.1$ & $26.3 \pm 0.3$ & $38.8 \pm 1.0$ \\
\hline & & $\mathrm{S}(n=3)$ & $18.2 \pm 0.1$ & $0.2 \pm 0.0$ & $18.5 \pm 0.2$ & $2.8 \pm 0.1$ & $10.7 \pm 0.2$ & $45.8 \pm 1.4$ \\
\hline & & $\mathrm{R}(n=3)$ & $11.9 \pm 0.7$ & $0.1 \pm 0.0$ & $13.0 \pm 0.1$ & $1.3 \pm 0.0$ & $6.7 \pm 0.1$ & $29.3 \pm 1.1$ \\
\hline & & $M(n=9)$ & $22.7 \pm 3.9 \mathrm{a}$ & $0.3 \pm 0.1 \mathrm{a}$ & $17.6 \pm 1.2 \mathrm{ab}$ & $3.2 \pm 0.6 \mathrm{ab}$ & $14.6 \pm 2.9 \mathrm{ab}$ & $38.0 \pm 2.5 b$ \\
\hline & & value & $3.4 * *$ & $5.2 * *$ & $2.2^{\mathrm{ns}}$ & $0.9^{\text {ns }}$ & $0.2^{\mathrm{ns}}$ & $0.3^{\text {ns }}$ \\
\hline \multirow{11}{*}{ L. esculentum } & \multirow{5}{*}{ SS } & $\mathrm{F}(n=3)$ & $43.1 \pm 0.2$ & $0.0 \pm 0.0$ & $5.0 \pm 0.0$ & $2.1 \pm 0.0$ & $4.1 \pm 0.1$ & $49.4 \pm 2.2$ \\
\hline & & $\mathrm{L}(n=3)$ & $50.4 \pm 0.7$ & $1.5 \pm 0.0$ & $50.9 \pm 1.1$ & $8.4 \pm 0.1$ & $9.9 \pm 0.2$ & $37.3 \pm 0.5$ \\
\hline & & $\mathrm{S}(n=3)$ & $40.6 \pm 0.9$ & $0.1 \pm 0.0$ & $37.0 \pm 0.5$ & $7.4 \pm 0.1$ & $15.6 \pm 0.3$ & $58.1 \pm 1.2$ \\
\hline & & $\mathrm{R}(n=3)$ & $33.0 \pm 0.4$ & $0.3 \pm 0.0$ & $52.7 \pm 0.7$ & $5.3 \pm 0.1$ & $8.9 \pm 0.1$ & $40.5 \pm 0.9$ \\
\hline & & $M(n=12)$ & $41.8 \pm 1.9 \mathrm{c}$ & $0.5 \pm 0.2 \mathrm{a}$ & $36.4 \pm 5.8 \mathrm{~b}$ & $5.8 \pm 0.7 \mathrm{ab}$ & $9.6 \pm 1.2 \mathrm{abc}$ & $46.3 \pm 2.5 a$ \\
\hline & \multirow{5}{*}{ RS } & $\mathrm{F}(n=3)$ & $27.5 \pm 2.3$ & $0.3 \pm 0.0$ & $4.7 \pm 0.0$ & $1.8 \pm 0.0$ & $5.8 \pm 0.1$ & $62.2 \pm 2.4$ \\
\hline & & $\mathrm{L}(n=3)$ & $38.0 \pm 0.6$ & $1.5 \pm 0.1$ & $80.9 \pm 2.4$ & $8.3 \pm 0.4$ & $14.6 \pm 0.7$ & $27.9 \pm 1.1$ \\
\hline & & $\mathrm{S}(n=3)$ & $30.3 \pm 0.1$ & $0.8 \pm 0.0$ & $49.0 \pm 1.1$ & $8.8 \pm 0.2$ & $18.7 \pm 1.2$ & $56.5 \pm 3.9$ \\
\hline & & $\mathrm{R}(n=3)$ & $20.6 \pm 0.4$ & $3.2 \pm 0.0$ & $45.8 \pm 0.6$ & $4.8 \pm 0.1$ & $14.0 \pm 0.5$ & $40.7 \pm 1.5$ \\
\hline & & M $(n=12)$ & $29.1 \pm 1.9 \mathrm{a}$ & $1.5 \pm 0.3 \mathrm{~cd}$ & $45.1 \pm 8.2 \mathrm{~d}$ & $5.9 \pm 0.9 \mathrm{ab}$ & $13.3 \pm 1.5 \mathrm{ab}$ & $46.8 \pm 4.2 \mathrm{~b}$ \\
\hline & & value & $15.0 * * *$ & $2.8^{*}$ & $2.0^{\text {ns }}$ & $0.2^{\mathrm{ns}}$ & $7.4 * * *$ & $0.2^{\mathrm{ns}}$ \\
\hline \multirow{8}{*}{ P. australis } & \multirow{4}{*}{ SS } & $\mathrm{L}(n=3)$ & $42.0 \pm 0.2$ & $1.4 \pm 0.0$ & $16.6 \pm 0.3$ & $2.2 \pm 0.0$ & $3.5 \pm 0.0$ & $27.5 \pm 0.7$ \\
\hline & & $\mathrm{S}(n=3)$ & $17.0 \pm 0.2$ & $2.1 \pm 0.4$ & $12.1 \pm 0.1$ & $1.2 \pm 0.0$ & $4.8 \pm 0.1$ & $36.5 \pm 0.9$ \\
\hline & & $\mathrm{R}(n=3)$ & $19.6 \pm 0.8$ & $1.4 \pm 0.5$ & $14.8 \pm 3.4$ & $2.5 \pm 0.8$ & $4.7 \pm 0.5$ & $34.4 \pm 1.0$ \\
\hline & & M $(n=9)$ & $24.5 \pm 3.1 \mathrm{a}$ & $1.6 \pm 0.3 b$ & $14.6 \pm 1.7 \mathrm{a}$ & $2.1 \pm 0.4 a$ & $4.4 \pm 0.3 \mathrm{ab}$ & $33.2 \pm 1.2 \mathrm{a}$ \\
\hline & \multirow{4}{*}{ RS } & $\mathrm{L}(n=3)$ & $29.5 \pm 0.6$ & $0.0 \pm 0.0$ & $8.7 \pm 0.1$ & $1.0 \pm 0.0$ & $6.2 \pm 0.1$ & $23.8 \pm 1.1$ \\
\hline & & $\mathrm{S}(n=3)$ & $14.2 \pm 1.3$ & $0.0 \pm 0.0$ & $8.3 \pm 0.1$ & $0.9 \pm 0.0$ & $16.1 \pm 0.5$ & $14.1 \pm 0.5$ \\
\hline & & $\mathrm{R}(n=3)$ & $13.1 \pm 0.5$ & $1.2 \pm 0.0$ & $9.8 \pm 0.2$ & $2.4 \pm 0.1$ & $19.5 \pm 0.9$ & $15.3 \pm 0.6$ \\
\hline & & M $(n=9)$ & $18.9 \pm 2.7 \mathrm{a}$ & $0.4 \pm 0.2 \mathrm{ab}$ & $8.9 \pm 0.2 a$ & $1.4 \pm 0.3 a$ & $13.9 \pm 2.0 \mathrm{ab}$ & $17.7 \pm 1.6 a$ \\
\hline
\end{tabular}




\begin{tabular}{|c|c|c|c|c|c|c|c|c|}
\hline & \multicolumn{2}{|c|}{$t$-value } & $6.2 * * *$ & $2.7 *$ & $3.2 * *$ & $1.0^{\mathrm{ns}}$ & $7.1 * * *$ & $7.2 * * *$ \\
\hline \multirow{9}{*}{ P. dioscoridis } & \multirow{4}{*}{ SS } & $\mathrm{L}(n=3)$ & $39.5 \pm 0.5$ & $2.6 \pm 0.0$ & $33.5 \pm 0.8$ & $6.7 \pm 0.1$ & $21.3 \pm 0.4$ & $30.3 \pm 0.6$ \\
\hline & & $\mathrm{S}(n=3)$ & $26.7 \pm 0.1$ & $0.6 \pm 0.0$ & $10.8 \pm 0.2$ & $4.8 \pm 0.1$ & $10.0 \pm 0.2$ & $34.3 \pm 0.9$ \\
\hline & & $\mathrm{R}(n=3)$ & $17.3 \pm 0.3$ & $1.3 \pm 0.0$ & $9.6 \pm 0.2$ & $1.9 \pm 0.0$ & $11.7 \pm 0.3$ & $45.7 \pm 1.4$ \\
\hline & & $M(n=9)$ & $27.8 \pm 3.2 \mathrm{ab}$ & $1.5 \pm 0.3 b$ & $18.0 \pm 3.9 a$ & $4.4 \pm 0.7 \mathrm{ab}$ & $14.4 \pm 1.8 \mathrm{bc}$ & $36.8 \pm 2.4 a$ \\
\hline & \multirow{4}{*}{$\mathrm{RS}$} & $\mathrm{L}(n=3)$ & $33.1 \pm 0.2$ & $1.8 \pm 0.0$ & $29.2 \pm 0.5$ & $6.2 \pm 0.0$ & $21.6 \pm 1.0$ & $51.5 \pm 1.2$ \\
\hline & & $\mathrm{S}(n=3)$ & $11.0 \pm 0.1$ & $0.2 \pm 0.0$ & $14.8 \pm 0.1$ & $2.6 \pm 0.0$ & $5.6 \pm 0.1$ & $52.9 \pm 2.0$ \\
\hline & & $\mathrm{R}(n=3)$ & $9.0 \pm 0.1$ & $1.5 \pm 0.0$ & $15.7 \pm 0.2$ & $2.3 \pm 0.0$ & $12.9 \pm 0.2$ & $41.4 \pm 1.1$ \\
\hline & & $M(n=9)$ & $17.7 \pm 3.9 a$ & $1.2 \pm 0.3 a b c d$ & $19.9 \pm 2.3 \mathrm{ab}$ & $3.7 \pm$ 0.6ab & $13.4 \pm 2.3 \mathrm{ab}$ & $48.6 \pm 2.0 b$ \\
\hline & \multicolumn{2}{|c|}{$t$-value } & $7.0 * * *$ & $2.1^{\mathrm{ns}}$ & $1.2^{\mathrm{ns}}$ & $1.9^{\mathrm{ns}}$ & $1.1^{\mathrm{ns}}$ & 2.9* \\
\hline \multirow{9}{*}{ P. oleracea } & \multirow{4}{*}{ SS } & $\mathrm{L}(n=3)$ & $45.3 \pm 0.1$ & $4.1 \pm 0.1$ & $46.1 \pm 0.9$ & $21.4 \pm 0.5$ & $7.2 \pm 0.1$ & $63.7 \pm 2.4$ \\
\hline & & $\mathrm{S}(n=3)$ & $59.7 \pm 0.2$ & $1.8 \pm 0.0$ & $18.2 \pm 0.2$ & $10.4 \pm 0.1$ & $4.3 \pm 0.1$ & $119.7 \pm 6.0$ \\
\hline & & $\mathrm{R}(n=3)$ & $39.7 \pm 0.1$ & $3.7 \pm 0.0$ & $18.1 \pm 0.2$ & $9.6 \pm 0.2$ & $4.0 \pm 0.0$ & $57.4 \pm 1.4$ \\
\hline & & M $(n=9)$ & $48.2 \pm 2.9 \mathrm{c}$ & $3.2 \pm 0.4 \mathrm{~d}$ & $27.5 \pm 4.7 \mathrm{ab}$ & $13.8 \pm 1.9 c$ & $5.2 \pm 0.5 \mathrm{ab}$ & $80.2 \pm 10.1 \mathrm{c}$ \\
\hline & \multirow{4}{*}{$\mathrm{RS}$} & $\mathrm{L}(n=3)$ & $40.1 \pm 1.1$ & $1.8 \pm 0.0$ & $28.8 \pm 0.5$ & $24.4 \pm 0.5$ & $37.5 \pm 0.7$ & $44.8 \pm 1.1$ \\
\hline & & $\mathrm{S}(n=3)$ & $27.1 \pm 0.1$ & $1.4 \pm 0.0$ & $12.8 \pm 0.1$ & $13.6 \pm 0.1$ & $22.3 \pm 0.6$ & $76.8 \pm 3.6$ \\
\hline & & $\mathrm{R}(n=3)$ & $24.6 \pm 0.1$ & $1.7 \pm 0.0$ & $11.0 \pm 0.4$ & $7.5 \pm 0.4$ & $8.7 \pm 0.3$ & $33.8 \pm 0.9$ \\
\hline & & $M(n=9)$ & $30.6 \pm 2.4 a$ & $1.6 \pm 0.1 d$ & $17.5 \pm 2.8 \mathrm{ab}$ & $15.2 \pm 2.5 c$ & $22.8 \pm 4.2 b$ & $51.8 \pm 6.5 b$ \\
\hline & \multicolumn{2}{|c|}{$t$-value } & $4.4 * *$ & $5.0 * *$ & $5.3 * *$ & $1.5^{\mathrm{ns}}$ & $4.8 * *$ & $6.4 * * *$ \\
\hline \multirow{9}{*}{$R$. dentatus } & \multirow{4}{*}{ SS } & $\mathrm{L}(n=3)$ & $34.5 \pm 0.1$ & $0.5 \pm 0.0$ & $20.2 \pm 0.3$ & $5.6 \pm 0.1$ & $17.5 \pm 0.6$ & $35.3 \pm 0.8$ \\
\hline & & $\mathrm{S}(n=3)$ & $21.6 \pm 0.1$ & $1.9 \pm 0.0$ & $17.7 \pm 0.6$ & $4.1 \pm 0.1$ & $18.7 \pm 0.8$ & $41.6 \pm 1.3$ \\
\hline & & $\mathrm{R}(n=3)$ & $17.9 \pm 0.8$ & $2.5 \pm 0.0$ & $22.1 \pm 0.3$ & $5.0 \pm 0.1$ & $20.3 \pm 1.0$ & $34.8 \pm 0.8$ \\
\hline & & $M(n=9)$ & $24.6 \pm 2.5 a$ & $1.6 \pm 0.3 b$ & $20.0 \pm 0.7 a$ & $4.9 \pm 0.2 \mathrm{ab}$ & $18.8 \pm 0.6 c$ & $37.2 \pm 1.2 \mathrm{a}$ \\
\hline & \multirow{4}{*}{$\mathrm{RS}$} & $\mathrm{L}(n=3)$ & $40.1 \pm 0.3$ & $1.6 \pm 0.0$ & $19.9 \pm 0.4$ & $9.1 \pm 0.1$ & $42.7 \pm 0.7$ & $47.7 \pm 1.1$ \\
\hline & & $\mathrm{S}(n=3)$ & $12.1 \pm 0.3$ & $2.1 \pm 0.0$ & $13.9 \pm 0.0$ & $5.3 \pm 0.1$ & $20.3 \pm 0.3$ & $41.4 \pm 0.9$ \\
\hline & & $\mathrm{R}(n=3)$ & $6.3 \pm 0.4$ & $0.0 \pm 0.0$ & $14.0 \pm 0.4$ & $4.8 \pm 0.1$ & $15.9 \pm 0.2$ & $22.3 \pm 0.5$ \\
\hline & & $M(n=9)$ & $19.5 \pm 5.2 \mathrm{a}$ & $1.3 \pm 0.3 \mathrm{bcd}$ & $15.9 \pm 1.0 \mathrm{ab}$ & $6.4 \pm 0.7 b$ & $26.3 \pm 4.2 b$ & $37.1 \pm 3.8 b$ \\
\hline & \multicolumn{2}{|c|}{$t$-value } & $1.9^{\mathrm{ns}}$ & $0.7^{\mathrm{ns}}$ & $3.6 * *$ & $2.8^{*}$ & $1.7^{\mathrm{ns}}$ & $0.1^{\mathrm{ns}}$ \\
\hline \multirow{9}{*}{ S. nigrum } & \multirow{4}{*}{ SS } & $\mathrm{L}(n=3)$ & $51.9 \pm 0.7$ & $2.4 \pm 0.0$ & $20.2 \pm 0.4$ & $3.7 \pm 0.1$ & $2.0 \pm 0.1$ & $53.4 \pm 1.1$ \\
\hline & & $\mathrm{S}(n=3)$ & $25.9 \pm 0.1$ & $1.4 \pm 0.2$ & $22.8 \pm 0.5$ & $2.6 \pm 0.0$ & $2.1 \pm 0.0$ & $58.4 \pm 1.5$ \\
\hline & & $\mathrm{R}(n=3)$ & $17.6 \pm 0.2$ & $2.8 \pm 0.0$ & $24.1 \pm 0.5$ & $1.6 \pm 0.0$ & $4.2 \pm 0.1$ & $39.0 \pm 1.2$ \\
\hline & & $M(n=9)$ & $31.8 \pm 5.2 \mathrm{ab}$ & $2.2 \pm 0.2 \mathrm{bcd}$ & $22.4 \pm 0.6 a$ & $2.6 \pm 0.3 \mathrm{ab}$ & $2.8 \pm 0.4 a$ & $50.3 \pm 3.0 \mathrm{ab}$ \\
\hline & \multirow{4}{*}{$\mathrm{RS}$} & $\mathrm{L}(n=3)$ & $41.1 \pm 4.4$ & $1.4 \pm 0.0$ & $37.5 \pm 0.3$ & $6.4 \pm 0.1$ & $6.2 \pm 0.2$ & $50.8 \pm 1.4$ \\
\hline & & $\mathrm{S}(n=3)$ & $14.8 \pm 0.7$ & $0.9 \pm 0.0$ & $35.0 \pm 0.3$ & $5.1 \pm 0.1$ & $5.8 \pm 0.3$ & $62.9 \pm 1.9$ \\
\hline & & $\mathrm{R}(n=3)$ & $11.7 \pm 0.1$ & $1.9 \pm 0.0$ & $40.4 \pm 0.4$ & $3.7 \pm 0.1$ & $6.3 \pm 0.0$ & $40.5 \pm 1.3$ \\
\hline & & $M(n=9)$ & $22.5 \pm 4.8 \mathrm{a}$ & $1.4 \pm 0.1 \mathrm{~cd}$ & $37.6 \pm 0.8 \mathrm{~cd}$ & $5.1 \pm 0.4 a b$ & $6.1 \pm 0.1 a$ & $51.4 \pm 3.3 b$ \\
\hline & \multicolumn{2}{|c|}{$t$-value } & 6.0**** & $7.6 * * *$ & $19.3 * * *$ & $24.4 * * *$ & $10.3 * * *$ & $1.1^{\mathrm{ns}}$ \\
\hline \multicolumn{3}{|c|}{$F$-value Sewage sludge dump site } & $5.7 * * *$ & $9.6 * * *$ & $8.3 * * *$ & $14.9 * * *$ & $19.8 * * *$ & $12.4 * * *$ \\
\hline \multicolumn{3}{|c|}{$F$-value Reference site } & $1.4^{\mathrm{ns}}$ & $5.9 * * *$ & $11.1 * * *$ & $16.5^{* * * *}$ & $17.7 * * *$ & $7.5 * * *$ \\
\hline
\end{tabular}

$\mathrm{t}$-values represent the paired t-test. Means in the same columns (for each site) followed by different letters are significantly different at $\mathrm{p}<0.05$ according to Tukey HSD test. F: fruit, L: leaf, S: stem, R: root, M: mean of tissues, $*$ : $p<0.05, * *: p<0.01, * * *: p<0.001$, ns: not significant (i.e., $\mathrm{p}>0.05$ ) 
Appendix 2. Significant Pearson correlation coefficient $(p<0.05)$ between macro-nutrients concentrations in soil and nine native plant species in north Nile Delta, Egypt. Above diagonal represent the positive correlations and below diagonal represent the negative correlations

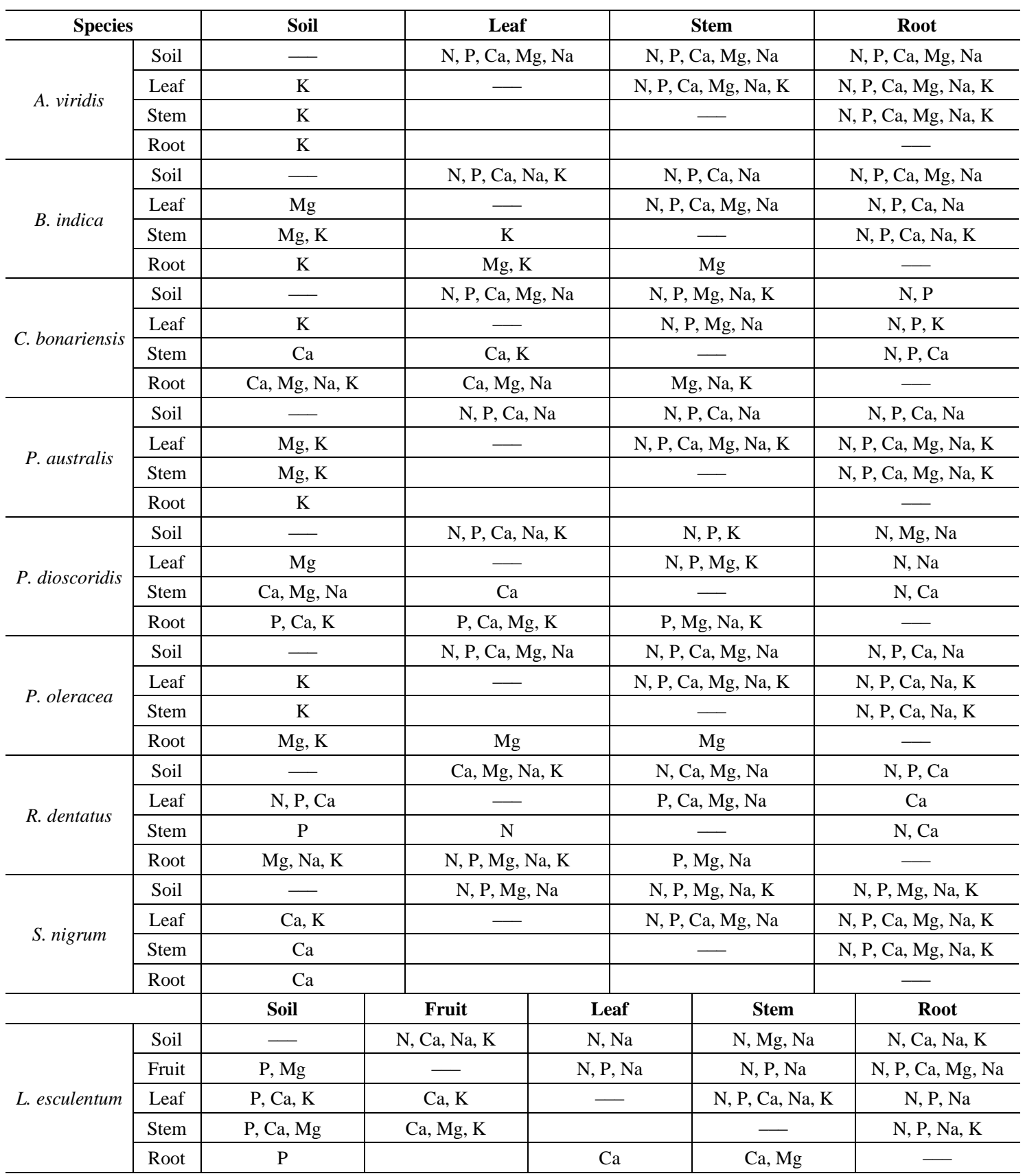

